\title{
Ecosystem metabolism in shallow coastal lagoons: patterns and partitioning of planktonic, benthic, and integrated community rates
}

\author{
Juliette C. P. Giordano, Mark J. Brush*, Iris C. Anderson \\ Virginia Institute of Marine Science, College of William and Mary, PO Box 1346, Gloucester Point, Virginia 23062, USA
}

\begin{abstract}
Net ecosystem metabolism (NEM) provides a quantifiable and integrative method for assessing the ecological responses of aquatic ecosystems to anthropogenic disturbance and has been shown to positively relate to nutrient enrichment in some systems. We measured NEM to determine the trophic status of 4 coastal lagoons receiving a range of nutrient loads on the Virginia/Maryland portion of the Delmarva Peninsula, USA. From July 2007 to July 2008, we used the component technique to assess NEM by developing photosynthesis-irradiance curves for both the water column and sediments approximately monthly; we added macroalgal incubations in the summer of 2008. We also measured in situ NEM by the open water method using 2 to 3 wk deployments of data sondes. Component incubations indicated net autotrophy in all 4 lagoons for March to October. No significant relationship existed between NEM and total nitrogen load overall, except for reduced autotrophy in the most enriched system. Light availability, sediment organic content, temperature and depth were all important regulators of NEM. Inclusion of macroalgal metabolism during summer 2008 had varied effects on system NEM. Open water and component methods gave divergent results. We attribute these differences to the adjacent marshes and the assumptions inherent in the 2 methods, demonstrating the need for careful attention to the method of choice for estimating system metabolism in these highly variable, shallow photic systems. Overall, NEM was net autotrophic, dominated by phytoplankton production across our study lagoons, and controlled by multiple factors.
\end{abstract}

KEY WORDS: Net ecosystem metabolism - Primary production · Respiration - Coastal lagoon · Phytoplankton $\cdot$ Microphytobenthos $\cdot$ Macroalgae

\section{INTRODUCTION}

Over half of the population in the United States resides in the coastal zone, making these regions the most developed in the nation (EPA 2008). Intensified development, population growth and expansion of agricultural activities have increased anthropogenic nitrogen loads to many coastal marine systems, resulting in reduced water quality and an increasing rate of supply of organic matter, or eutrophication (Nixon 1995, Bricker et al. 1999, 2008, Howarth \& Marino 2006, Howarth 2008). Eutrophication has serious implications for the health of coastal eco- systems and can lead to adverse shifts in ecosystem structure and function (Valiela et al. 1992, 1997, Bricker et al. 1999, 2008, Cloern 2001, Boesch 2002, McGlathery et al. 2007).

Coastal lagoons, characterized by shallow depths of 1 to $2 \mathrm{~m}$ and well-mixed water columns, serve an important role as a filter for organic matter and nutrients traversing to the ocean (McGlathery et al. 2001, Anderson et al. 2003). They support a wide variety of primary producers and substantial benthic communities (Boynton et al. 1996, Nixon et al. 2001, McGlathery et al. 2007), and serve as critical habitats, spawning grounds and nurseries for numerous fish and 
shellfish species (Beck et al. 2001, 2003, Able 2005, EPA 2008). The close proximity of shallow marine systems to land, their small volumes and relatively long residence times, and the penetration of light to the benthos make these systems particularly susceptible to nutrient enrichment (Duarte 1995, Bricker et al. 1999, McGlathery et al. 2007). Microphytobenthos (MPB), however, may help mediate the response of shallow systems to nutrient loading (Tobias et al. 2003, Anderson et al. 2010).

Although nitrogen loads to coastal lagoons are of a magnitude similar to those of deeper estuaries, responses in shallow lagoons appear to be quite different, likely because of enhanced benthic-pelagic coupling (Nixon et al. 2001, McGlathery et al. 2007). An illuminated benthos results in a significant contribution of MPB, seagrasses and macroalgae to total system production. Under extremely high nitrogen loads, however, bloom-forming macroalgae and, ultimately, phytoplankton can dominate, shading out MPB, seagrasses and slow-growing macroalgae (Borum \& Sand-Jensen, 1996, Valiela et al. 1997).

Interactions between autotrophic communities are complex and predictive patterns between nutrient loading and a single component of the system often do not hold in shallow systems as they do in deeper estuaries (Cloern 2001, Nixon et al. 2001, Howarth \& Marino 2006). An understanding of how changes in nutrient regime affect shallow systems requires broad ecosystem-scale evaluations incorporating different processes mediating trophic response (Cloern 2001).

Net ecosystem metabolism (NEM) is an easily quantifiable and integrative measure for assessing the trophic status of a system, and may also be useful for quantifying the response to stressors including nutrient enrichment (Kemp \& Boynton 1980, D'Avanzo et al. 1996, Kemp et al. 1997). Defined as the difference between gross primary production (GPP) and community respiration (R), NEM is an indicator of how a system processes nutrients and organic material (Smith \& Hollibaugh 1997). A system with positive NEM (in oxygen units) is net autotrophic, producing more organic matter than is consumed through net assimilation of inorganic nutrients. Conversely, a system with negative NEM (in oxygen units) is net heterotrophic with a potential net export of inorganic nutrients and a net import or storage of organic matter (Eyre \& McKee 2002, Hopkinson \& Smith 2004). NEM measurements inherently incorporate complex processes influencing primary production and respiration and are a useful tool for assessing the trophic status and response of shallow ecosystems.
NEM can be driven by organic matter loading (Smith \& Hollibaugh 1997), inorganic nutrient loading (Oviatt et al. 1986, Eyre \& McKee 2002, Caffrey 2004 ) or the ratio of inorganic to organic nutrient loads (Kemp et al. 1997). Other factors in addition to nutrient loading have also been found to influence NEM, such as light availability, temperature, depth, surrounding habitat, concentrations of water column dissolved organic carbon (DOC) and salinity (Caffrey 2003，2004, Rochelle-Newall et al. 2007, Russell \& Montagna 2007, Murrell et al. 2009).

In the present study, we aimed to elucidate the primary controls on NEM in coastal lagoons along the Virginia and Maryland portion of the Delmarva Peninsula, USA. We used metabolic measurements as an indicator of system trophic status in 4 temperate coastal lagoons with a range of total nitrogen (TN) loads. We measured metabolic processes from July 2007 to July 2008 using oxygen-based component (e.g. Kemp et al. 1997, Smith \& Hollibaugh 1997) and open-water (e.g. Odum \& Hoskins 1958) methods. The ultimate goal of this project was to determine the main drivers of NEM in these lagoons, quantify the relative contribution of pelagic and benthic producers, and compare component and open-water methods for assessing NEM in these highly dynamic, shallow systems.

\section{MATERIALS AND METHODS}

\section{Site description}

This study focused on 4 coastal lagoons on the Delmarva Peninsula characterized by a range of areal TN loads, attributable to varying land use within each watershed (Fig. 1, Table 1). We focus on nitrogen rather than phosphorus loads as high salinity systems in this region tend to be N-limited, particularly during the summer growing season (Fisher et al. 1999), and dissolved inorganic N:P ratios in our lagoons were almost always well below the Redfield ratio (Table 2). These systems have shallow water depths $(\sim 1 \mathrm{~m})$, illuminated sediments and well-mixed water columns. Water quality and sediment characteristics are detailed in Table 2.

\section{Field monitoring and sampling}

From July 2007 through July 2008, the 3 Virginia lagoons were sampled in March and then monthly from May through October; sampling in Isle of Wight 


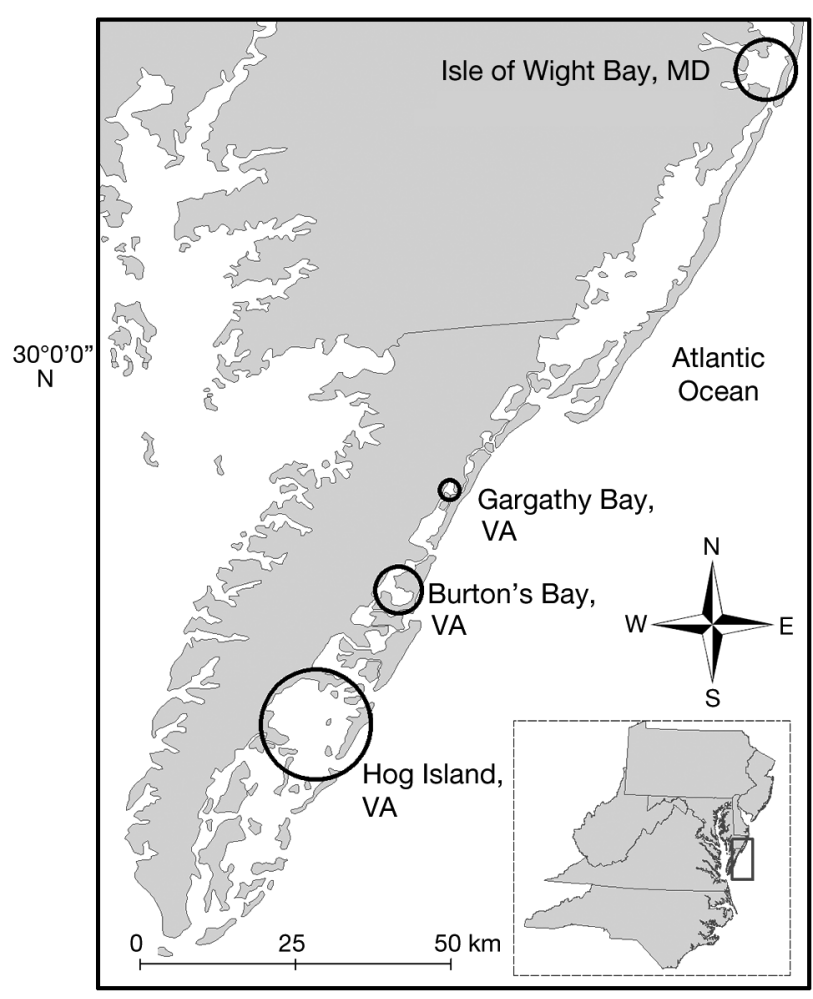

$75^{\circ} 0^{\prime} 0^{\prime \prime} \mathrm{W}$

Fig. 1. Study sites on the Delmarva Peninsula, USA. Sampling occurred at 3 sites along a creek-to-inlet transect within each bay, except for Gargathy Bay, which, because of its small size, had a single mid-bay site

Bay, MD, occurred monthly from July to September 2007 and then bi-monthly from March to July 2008 because of logistical constraints (Fig. 1). Within Hog Island, Isle of Wight and Burton's Bays, samples were taken at the mouth of the contributing creek, at midbay and near the inlet; only one mid-bay sampling site was established in Gargathy Bay because of its small size. Temperature $\left({ }^{\circ} \mathrm{C}\right)$, salinity and dissolved oxygen (DO) were measured at each site using a handheld datasonde. LiCor $2 \pi$ surface and underwater quantum sensors were used to determine irradiance at the surface, at the bottom and at 10 to $20 \mathrm{~cm}$ increments through the water column depending on depth. Irradiance data were used to determine vertical attenuation coefficients, $k_{\mathrm{D}}$, at each site.

At each sampling station, water column chlorophyll a (chl a) was collected on Whatman GF/F filters, extracted using the method of Shoaf \& Lium (1976), and analyzed fluorometrically before and after acidification. Concentrations of dissolved inorganic nitrogen and phosphorus and dissolved organic nitrogen (DIN, DIP and DON, respectively) were measured after filtration (0.45 $\mathrm{m}$ Gelman Supor filters) on a Lachat auto analyzer (Smith \& Bogren 2001, Liao 2001, Knepel \& Bogren 2001) and by persulfate digestion in sealed ampules (Knepel \& Bogren 2001), respectively.

Sediment samples for benthic chl $a$ were sectioned into $0-3$ and $3-10 \mathrm{~mm}$ fractions, extracted using the method of Pinckney \& Zingmark (1993), and analyzed spectrophotometrically before and after acidification using the equations of Lorenzen (1967). Sediment samples for percent organics and bulk density were taken to a depth of $10 \mathrm{~cm}$.

During the summer of 2008, macroalgae were collected for determination of biomass in Gargathy and Burton's Bays to complement existing measurements of mean monthly biomass in Hog Island and Isle of Wight Bays from May to September 2006 and 2007 (Hardison et al. 2010). Macroalgae were randomly sampled in triplicate at each station using a $0.14 \mathrm{~m}^{2}$ ring and, upon return to the laboratory, were rinsed

Table 1. Physical characteristics of the 4 study lagoons. Percent of watershed area in major land-use categories is given for agriculture, natural vegetation and impervious surfaces based on the 2001 National Land Cover Dataset (Homer et al. 2004)

\begin{tabular}{|c|c|c|c|c|c|c|c|c|}
\hline \multirow{2}{*}{ Lagoon } & \multirow{2}{*}{$\begin{array}{c}\text { Total nitrogen } \\
\text { load } \\
\left(\mathrm{g} \mathrm{N} \mathrm{m}^{-2} \mathrm{yr}^{-1}\right)\end{array}$} & \multirow{2}{*}{$\begin{array}{c}\text { Watershed } \\
\text { area } \\
\left(\mathrm{m}^{2}\right)\end{array}$} & \multirow{2}{*}{$\begin{array}{c}\text { Marsh } \\
\text { area } \\
\left(\mathrm{m}^{2}\right)\end{array}$} & \multirow{2}{*}{$\begin{array}{c}\text { Lagoon } \\
\text { surface area } \\
\qquad\left(\mathrm{m}^{2}\right)\end{array}$} & \multirow{2}{*}{$\begin{array}{l}\text { Tidal } \\
\text { range }^{\mathrm{a}} \\
(\mathrm{m})\end{array}$} & \multicolumn{3}{|c|}{- Percent of watershed } \\
\hline & & & & & & Agriculture & $\begin{array}{c}\text { Natural } \\
\text { vegetation }\end{array}$ & Impervious \\
\hline Hog Island Bay, VA & $1.4^{\mathrm{b}}$ & $9.2 \times 10^{7}$ & $3.3 \times 10^{7}$ & $1.5 \times 10^{8}$ & 1.3 & 31 & 60 & 7 \\
\hline Burton's Bay, VA & $4.4^{\mathrm{c}}$ & $6.0 \times 10^{7}$ & $1.1 \times 10^{7}$ & $1.8 \times 10^{7}$ & 1.2 & 42 & 47 & 7 \\
\hline Isle of Wight Bay, MD & $6.5^{\mathrm{d}}$ & $1.8 \times 10^{7}$ & $1.2 \times 10^{7}$ & $1.6 \times 10^{7}$ & 0.67 & 32 & 40 & 13 \\
\hline Gargathy Bay, VA & $25^{\mathrm{c}}$ & $2.8 \times 10^{7}$ & $2.7 \times 10^{6}$ & $1.2 \times 10^{6}$ & 0.91 & 49 & 40 & 6 \\
\hline \multicolumn{9}{|c|}{$\begin{array}{l}{ }^{a} \text { NOAA tide predictions (http://tidesandcurrents.noaa.gov/tide_predictions.shtml; NOAA/NOS Center for Operational } \\
\text { Oceanographic Products and Services) } \\
\text { bStanhope et al. (2009); load includes base flow and atmospheric deposition to the lagoon surface } \\
\text { cGiordano et al. (2011); load includes base flow and atmospheric deposition to the lagoon surface } \\
\text { dBoynton et al. (1996); load includes storm flow and point sources in addition to base flow and atmospheric deposition to } \\
\text { lagoon surface }\end{array}$} \\
\hline
\end{tabular}


Table 2. Mean $( \pm \mathrm{SE})$ water quality and sediment characteristics of the 4 lagoons for March to October. Macroalgal biomass represents average biomass for May-July on a gram dry mass (g DM) basis. $k_{\mathrm{D}}$; water attenuation coefficient; DIN: dissolved inorganic nitrogen; DON: dissolved organic nitrogen

\begin{tabular}{|c|c|c|c|c|c|c|c|c|c|c|c|}
\hline Lagoon & $\begin{array}{l}\text { Temp } \\
\left({ }^{\circ} \mathrm{C}\right)\end{array}$ & Salinity & $\begin{array}{l}\text { Water } \\
\text { column chl } a \\
\left(\mathrm{mg} \mathrm{m}^{-3}\right)\end{array}$ & $\begin{array}{l}\text { Sediment } \\
\quad \text { chl a } \\
\left(0-3 \mathrm{~mm}^{-2}\right. \\
\left.\mathrm{mg} \mathrm{m}^{-2}\right)\end{array}$ & $\begin{array}{c}k_{\mathrm{D}} \\
\left(\mathrm{m}^{-1}\right)\end{array}$ & $\begin{array}{l}\text { DIN } \\
(\mu \mathrm{M})\end{array}$ & $\begin{array}{l}\text { DON } \\
(\mu \mathrm{M})\end{array}$ & $\begin{array}{l}\mathrm{PO}_{4} \\
(\mu \mathrm{M})\end{array}$ & $\begin{array}{c}\text { Sediment } \\
\text { organic } \\
\text { content } \\
(\%)\end{array}$ & $\begin{array}{c}\text { Ulva } \\
\text { biomass } \\
\left(\mathrm{g} \mathrm{DM} \mathrm{m}^{-2}\right)\end{array}$ & $\begin{array}{c}\text { Gracilaria } \\
\text { biomass } \\
\left(\mathrm{g} \mathrm{DM} \mathrm{m}^{-2}\right)\end{array}$ \\
\hline $\begin{array}{l}\text { Hog Island } \\
\text { Bay, VA }\end{array}$ & $24.3 \pm 0.3$ & $33.1 \pm 0.4$ & $8.0 \pm 2.6$ & $37.7 \pm 5.9$ & $2.2 \pm 0.3$ & $3.6 \pm 1.2$ & $17.1 \pm 2.0$ & $0.8 \pm 0.1$ & $1.8 \pm 0.3$ & $3.52 \pm 1.43$ & $7.72 \pm 3.78$ \\
\hline $\begin{array}{l}\text { Burton's } \\
\text { Bay, VA }\end{array}$ & $22.0 \pm 0.2$ & $33.0 \pm 0.8$ & $10.5 \pm 3.0$ & $20.9 \pm 6.0$ & $2.0 \pm 0.7$ & $3.3 \pm 1.1$ & $18.7 \pm 1.6$ & $0.7 \pm 0.1$ & $2.7 \pm 0.3$ & $19.0 \pm 4.41$ & $17.7 \pm 9.16$ \\
\hline $\begin{array}{l}\text { Gargathy } \\
\text { Bay, VA }\end{array}$ & $21.5 \pm 2.3$ & $31.7 \pm 0.7$ & $10.9 \pm 3.1$ & $54.7 \pm 28.4$ & $2.8 \pm 0.9$ & $4.8 \pm 1.4$ & $23.6 \pm 3.6$ & $0.6 \pm 0.1$ & $3.9 \pm 0.5$ & $47.2 \pm 29.6$ & $652 \pm 302$ \\
\hline
\end{tabular}

in distilled water, separated by genus (i.e. Gracilaria, Ulva and other) and weighed fresh. All biomass estimates included samples with zero biomass to account for the spatial patchiness of the macroalgae. Hardison's measurements were reported in dry mass, and we used an average wet:dry mass ratio (Brush 2002) to convert these measurements into wet mass for comparison to our measurements.

\section{System metabolic measurements}

\section{Component method}

System metabolism was calculated based on DO fluxes measured during light-dark incubations of ambient water and sediments with overlying filtered water. At each site, water samples were collected in 21 blackened Nalgene bottles and $15 \mathrm{~cm}$ sediment cores $(7 \mathrm{~cm}$ sediment depth; $3.1 \mathrm{~cm}$ i.d.) were collected and kept on ice until return to the laboratory. Cores were allowed to sit uncovered overnight in the dark in a circulating seawater bath at ambient temperatures. From May to July 2008, Gracilaria spp. and Ulva spp. were collected from each site (when present) for determination of macroalgal metabolism.

All incubations were conducted in a flow-through light gradient box maintained at in situ temperatures with photosynthetically active radiation (PAR) ranging from $\sim 60$ to $\sim 2000 \mu \mathrm{E} \mathrm{m}^{-2} \mathrm{~s}^{-1}$. DO concentrations were measured before and after incubations using luminescent DO probes. On the day of collection, 10 water samples per site were incubated in $60 \mathrm{ml}$ biological oxygen demand (BOD) bottles at 10 different light levels for approximately $1 \mathrm{~h}$, and 3 bottles per site were incubated in the dark for $24 \mathrm{~h}$ to obtain a measurable change in oxygen.
Sediment cores were incubated the day following collection with 10 cores at 10 different light levels and 3 in the dark. Immediately before core incubation, overlying water was siphoned out of each core and replaced with filtered site water $(0.45 \mu \mathrm{m})$, and core tops were sealed with polyethylene (Saran Wrap ${ }^{\mathrm{TM}}$ ), which has a low oxygen permeability of 5.8 $\times 10^{-5} \mathrm{ml} \mathrm{cm}^{-2} \mathrm{~h}^{-1}$ (Pemberton et al. 1996). Cores were incubated unstirred but incubations were kept short (1 to $2 \mathrm{~h}$ ) to minimize build-up of diffusion gradients. Before taking final DO measurements, the overlying water was gently mixed to obtain a composite sample.

Macroalgae were acclimated in the light for $\sim 30 \mathrm{~min}$ to $1 \mathrm{~h}$ on the day of collection, after which approximately 100 to $150 \mathrm{mg}$ (wet) of Ulva and Gracilaria were incubated separately in $60 \mathrm{ml}$ BOD bottles with filtered seawater at 10 light levels and in the dark as for the water column incubations. All algal samples were weighed post-incubation after rinsing with distilled water to normalize rates to biomass.

Photosynthesis-irradiance (PI) curves were developed from changes in DO concentrations over the range of PAR used in each experiment (Fig. 2). The Jassby \& Platt (1976) PI model was fit to hourly metabolic rates from all incubations after it was determined to best fit our data using an information theoretic approach (Burnham \& Anderson 2002, Giordano 2009):

$$
\text { Photosynthesis }=P_{\max } \cdot \tanh \left(\frac{\alpha \cdot I}{P_{\max }}\right)-R
$$

where $P_{\max }\left(\mathrm{mg} \mathrm{O}_{2} \mathrm{l}^{-1} \mathrm{~h}^{-1}\right)$ is the maximum rate of photosynthesis, $\alpha\left(\mathrm{mg} \mathrm{O}_{2} \mathrm{l}^{-1} \mathrm{~h}^{-1}\left[\mu \mathrm{E} \mathrm{m}^{-2} \mathrm{~s}^{-1}\right]^{-1}\right)$ is photosynthetic efficiency or the initial slope of the PI curve, $I$ is irradiance (PAR; $\left.\mu \mathrm{E} \mathrm{m}^{-2} \mathrm{~s}^{-1}\right)$ and $R\left(\mathrm{mg} \mathrm{O}_{2}\right.$ $\mathrm{l}^{-1} \mathrm{~h}^{-1}$ ) is respiration. Using model estimates of $P_{\max } \alpha$ 

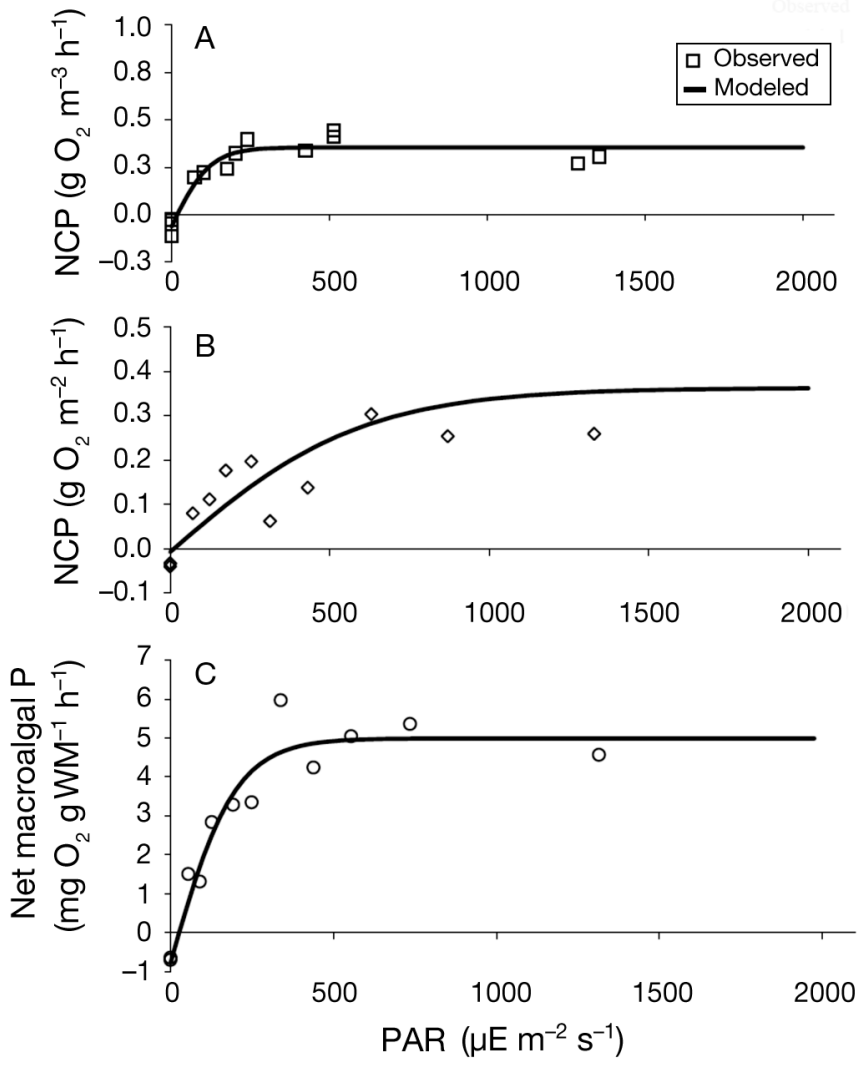

Fig. 2. Sample photosynthesis-irradiance curves for (A) water, (B) sediments and (C) macroalgae fit to the Jassby \& Platt (1976) equation. NCP: net community production; WM: wet mass and $R$ (Table 3 ) and mean hourly PAR for each month (see below), daily rates of gross primary production (GPP), $R$, net community production (NCP) and NEM were calculated for each sampling date. Water column metabolism was depth integrated for a $1 \mathrm{~m}$ water column (average depth of the lagoons) using measured values of $k_{\mathrm{D}}$ and assuming a constant respiration rate for the $24 \mathrm{~h}$ period. Production and respiration were computed in $10 \mathrm{~cm}$ depth intervals using incident PAR attenuated over depth. Sediment metabolism was similarly based on a water depth of $1 \mathrm{~m}$ with constant $24 \mathrm{~h} R$.

Calculations of macroalgal metabolism for summer 2008 used estimated mat thicknesses from field biomass estimates and a relationship of mat thickness to biomass for Gracilaria tikvahiae (Peckol \& Rivers 1996). Mean hourly irradiance values for each month were used to compute the average hourly PAR $(\bar{I})$ experienced within the mixed assemblage mat of Ulva and Gracilaria as:

$$
\bar{I}=\frac{I_{M}\left(1-\mathrm{e}^{-\left(k_{\mathrm{D}} \cdot z_{\mathrm{mat}}+k_{\mathrm{t}} \cdot n_{\mathrm{T}}+k_{\mathrm{G}} \cdot B_{\mathrm{G}}\right)}\right)}{\left(k_{D} \cdot z_{\mathrm{mat}}+k_{\mathrm{t}} \cdot n_{\mathrm{T}}+k_{\mathrm{G}} \cdot B_{\mathrm{G}}\right)}
$$

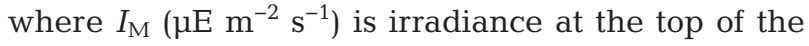
mat, $k_{\mathrm{D}}\left(\mathrm{m}^{-1}\right)$ is attenuation by the water within the mat, $z_{\text {mat }}$ is mat thickness, $k_{\mathrm{t}}$ is attenuation per thallus of Ulva (Brush and Nixon 2003), $n_{\mathrm{T}}$ is the number of Ulva thalli (Brush \& Nixon 2003), $k_{\mathrm{G}}$ is the attenuation of light through the Gracilaria mat calculated

Table 3. March to October mean, minimum and maximum water column, sediment and macroalgal (Ulva and Gracilaria) photosynthesis-irradiance (PI) parameters for each bay. Units for maximum photosynthesis $\left(P_{\max }\right)$ and respiration $(R)$ are mg $\mathrm{O}_{2} \mathrm{l}^{-1}$

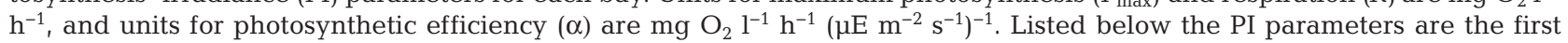
and third quartiles for the $\mathrm{p}$-values for the water column, sediment and macroalgae PI fits from March to October

\begin{tabular}{|c|c|c|c|c|c|c|c|c|c|c|c|c|}
\hline \multirow[t]{2}{*}{ Lagoon } & \multicolumn{3}{|c|}{ Water column } & \multicolumn{3}{|c|}{ Sediment } & \multicolumn{3}{|c|}{ Ulva } & \multicolumn{3}{|c|}{ Gracilaria } \\
\hline & $P_{\max }$ & $\alpha$ & $R$ & $P_{\max }$ & $\alpha$ & $R$ & $P_{\max }$ & $\alpha$ & $R$ & $P_{\max }$ & $\alpha$ & $R$ \\
\hline \multicolumn{13}{|l|}{ Hog Island Bay, VA } \\
\hline Mean & 0.37 & 0.22 & -0.03 & 2 & 0.01 & -0.4 & 80 & 0.68 & -7.4 & 42 & 0.08 & -3.9 \\
\hline Minimum & 0.07 & 0 & -0.08 & 0.15 & 0 & -1.2 & 40 & 0.18 & -17 & 21 & 0.03 & -9.2 \\
\hline Maximum & 0.91 & 1.66 & 0 & 3.7 & 0.04 & 0 & 170 & 1.12 & -2.3 & 64 & 0.13 & -1.9 \\
\hline $\mathrm{p}$-value quartiles & \multicolumn{3}{|c|}{$<0.01,0.00$} & \multicolumn{3}{|c|}{$<0.01,0.02$} & \multicolumn{3}{|c|}{$<0.01,<0.01$} & \multicolumn{3}{|c|}{$<0.01,<0.01$} \\
\hline \multicolumn{13}{|l|}{ Burton's Bay, VA } \\
\hline Mean & 0.44 & 0.08 & -0.06 & 2.2 & 0.01 & -0.04 & 84 & 0.57 & -6.54 & 86 & 0.15 & -11 \\
\hline Minimum & 0.03 & 0 & -0.47 & 0.38 & 0 & -0.71 & 41 & 0.2 & -13 & 23 & 0.11 & -22 \\
\hline Maximum & 0.87 & 0.75 & 0 & 6.3 & 0.04 & -0.07 & 110 & 0.86 & -3.1 & 180 & 0.27 & -5.7 \\
\hline p-value quartiles & \multicolumn{3}{|c|}{$<0.01,0.01$} & \multicolumn{3}{|c|}{$<0.01,0.01$} & \multicolumn{3}{|c|}{$<0.01,0.00$} & \multicolumn{3}{|c|}{$<0.01,0.01$} \\
\hline \multicolumn{13}{|l|}{ Isle of Wight Bay, MD } \\
\hline Mean & 0.25 & 0.31 & -0.02 & 2.5 & 0.01 & -0.38 & 56 & 0.5 & -4.8 & 27 & 0.11 & -4.42 \\
\hline Minimum & -0.05 & 0 & -0.12 & 0.82 & 0 & -0.63 & 1.1 & 0.34 & -7.9 & 14 & 0.07 & -7.5 \\
\hline Maximum & 0.66 & 1 & 0 & 3.8 & 0.03 & -0.1 & 93 & 0.58 & -1.3 & 42 & 0.21 & -2.5 \\
\hline p-value quartiles & \multicolumn{3}{|c|}{$<0.01,0.04$} & \multicolumn{3}{|c|}{$<0.01,0.03$} & \multicolumn{3}{|c|}{$<0.01,0.22$} & \multicolumn{3}{|c|}{$<0.01,<0.01$} \\
\hline \multicolumn{13}{|l|}{ Gargathy Bay, VA } \\
\hline Mean & 0.4 & 0.14 & -0.06 & 1.6 & 0 & -0.6 & 33 & 0.18 & -6.1 & 14 & 0.05 & -3.8 \\
\hline Minimum & 0.09 & 0 & -0.19 & 0.67 & 0 & -0.99 & -1.7 & 0.01 & -9.4 & 2 & 0.01 & -9.1 \\
\hline Maximum & 0.67 & 0.96 & 0 & 2.7 & 0.01 & -0.09 & 67 & 0.34 & -2.3 & 30 & 0.13 & -0.55 \\
\hline p-value quartiles & \multicolumn{3}{|c|}{$<0.01,0.04$} & \multicolumn{3}{|c|}{$<0.01,0.06$} & \multicolumn{3}{|c|}{$0.02,0.37$} & \multicolumn{3}{|c|}{$0.02,0.03$} \\
\hline
\end{tabular}


based on a relationship between percent light transmission and biomass of Gracilaria (Brush 2002) and $B_{\mathrm{G}}$ is Gracilaria dry mass. These hourly light levels, $\bar{I}$, were combined with biomass-normalized macroalgal $\alpha, P_{\max }$ and $R$ to scale up to daily mat metabolism in each month as for the water column and sediment incubations. Measured biomass at each site was used to extrapolate to in situ metabolism; however, given the inherent patchiness of macroalgae in these systems and our limited sampling for biomass, our estimates of macroalgal metabolism apply only at our sampling stations and not at the scale of the entire lagoon.

Finally, sediment production in May, June and July 2008 was adjusted to account for macroalgal shading of the sediment surface based on average macroalgal biomass each month. The following equation was used to calculate light at the sediment surface $\left(I_{\text {sed }}\right)$ under a $1 \mathrm{~m}$ water column and a given mat thickness:

$$
I_{\text {sed }}=I_{\mathrm{o}} \mathrm{e}^{-\left(k_{\mathrm{D}} \cdot z+k_{\mathrm{t}} \cdot n_{\mathrm{T}}+k_{\mathrm{G}} \cdot B_{\mathrm{G}}\right)}
$$

where $I_{\mathrm{o}}\left(\mu \mathrm{E} \mathrm{m} \mathrm{m}^{-2} \mathrm{~s}^{-1}\right)$ is light at the surface, $k_{\mathrm{D}}\left(\mathrm{m}^{-1}\right)$ is the water column attenuation, $z(\mathrm{~m})$ is water depth and the other variables are as defined for Eq. (2).

Site-specific irradiance was unavailable, so hourly PAR data from Taskinas Creek, VA, approximately $100 \mathrm{~km}$ to the west, collected by the Chesapeake Bay National Estuarine Research Reserve of Virginia (CBNERRVA), were used. To ensure that CBNERRVA data applied to the Delmarva Peninsula, daily Taskinas Creek PAR values were compared with values collected at the University of Maryland Horn Point Laboratory located on the Delmarva (Fisher et al. 2003, T. R. Fisher \& A. B. Gustafson pers. comm.). Regression analyses indicated strong relationships between daily PAR at these 2 sites for 2006 $\left(\mathrm{r}^{2}=0.74, \mathrm{p}<0.001\right), 2007\left(\mathrm{r}^{2}=0.82, \mathrm{p}<0.001\right)$ and $2008\left(\mathrm{r}^{2}=0.81, \mathrm{p}<0.001\right)$.

\section{Open-water method}

Datasondes with optical DO sensors were deployed $0.5 \mathrm{~m}$ below the water surface near mid-bay in Burton's (5 deployments) and Gargathy (4 deployments) Bays, recording DO, percent saturation, temperature and salinity every 15 min during deployments of 7 to 18 d. NEM was computed from hourly average DO concentrations after correcting for air-sea exchange using the regression of Marino \& Howarth (1993), which calculates the transfer velocity as a function of wind speed recorded at the nearby Wallops Island Flight Facility Airport and obtained from the NOAA
National Climatic Data Center. Hourly NEM was integrated over $24 \mathrm{~h}$ to obtain daily rates.

\section{Statistical analyses}

General linear model (GLM) ANOVA was used to determine statistical significance among metabolic parameters across bays, sampling dates and locations (i.e. creek, mid bay and inlet). Differences were determined for daily GPP, $R$ and NCP and hourly $R$ and $P_{\max }$ for the water column and sediments, NEM, production:respiration $(P: R)$ and benthic:pelagic metabolism. In addition, differences were determined between rates scaled to reflect the growing season (March-October) and summer period when macroalgal incubations were included (May-July). Differences were considered significant at $\alpha=0.05$. A Tukey's pair-wise comparison test was used to determine differences between factors from significant ANOVA tests.

Data were first tested for normality and for homogeneity of variance. All data met the homogeneity of variance assumption, though not all data were normally distributed; transformation of the data did not improve the distribution. ANOVAs are robust to nonnormality, however, and the assumption of homogenous variance is more important to reduce the potential of Type I error (Quinn \& Keough 2002). As an independent check, non-parametric Kruskal-Wallis tests were run on the data and produced similar results.

\section{RESULTS}

\section{Daily gross primary production and respiration}

No statistical differences were found among sites for average daily water column GPP ( $p=0.885)$, water column NCP $(\mathrm{p}=0.075)$, sediment GPP $(\mathrm{p}=$ $0.880)$, sediment $R(\mathrm{p}=0.160)$ or sediment $\mathrm{NCP}(\mathrm{p}=$ $0.715)$, and interaction effects with site were also non-significant. The GLM ANOVA detected a statistical difference in water column $R$ among sites ( $\mathrm{p}=$ 0.012 ), but this difference did not appear to influence the overall metabolic balance of the water column as daily net metabolism did not differ among sites. Therefore, the 3 sites within each bay were treated as replicates and are presented as bay-wide averages throughout the paper.

All bays experienced higher pelagic GPP in the fall and late spring/early summer, low pelagic GPP in 

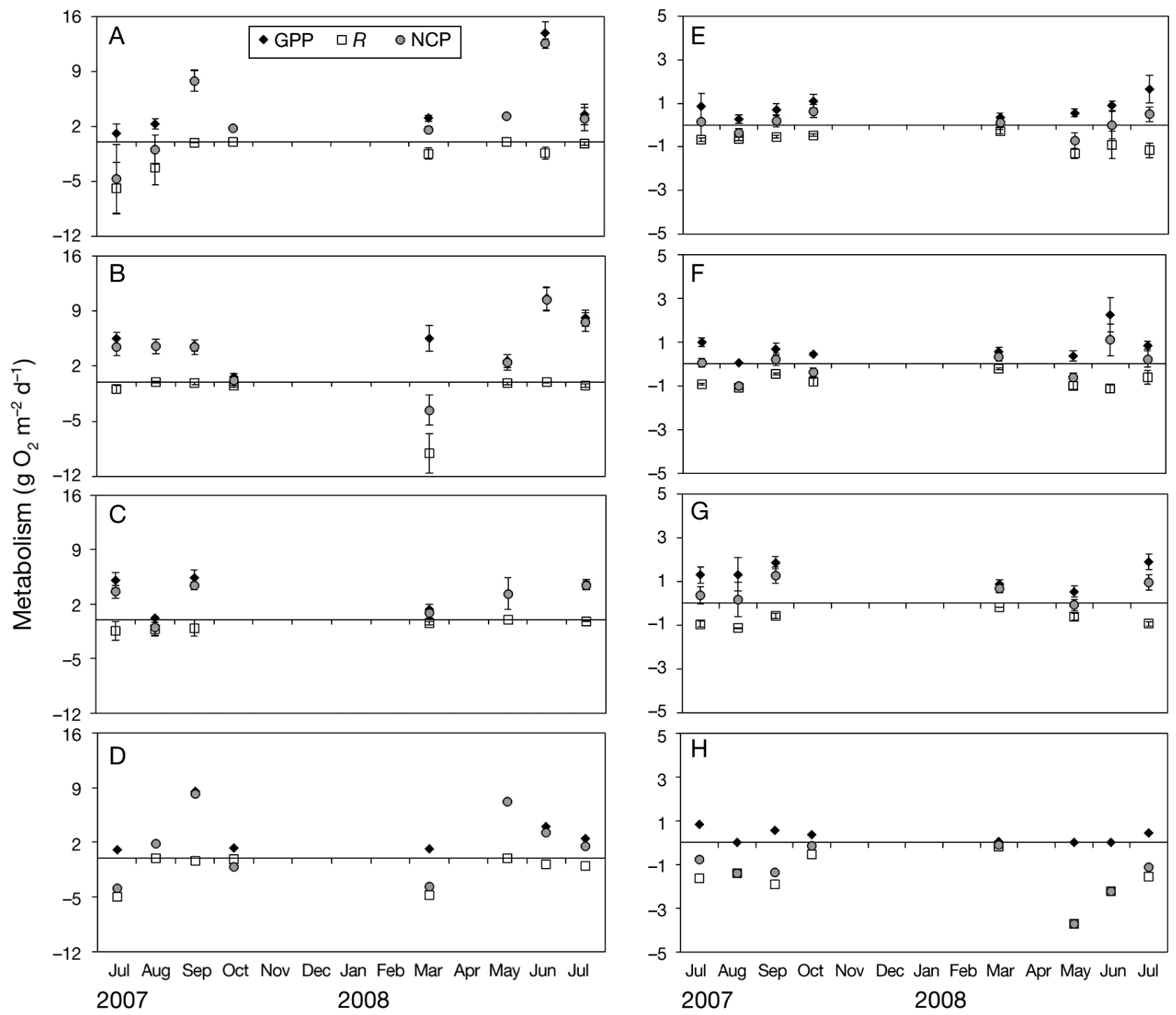

Fig. 3. Measured daily water column (A-D) and sediment (E-H) gross primary production (GPP), net community production $(\mathrm{NCP})$ and respiration $(R)$ for $(\mathrm{A}, \mathrm{E})$ Hog Island, $(\mathrm{B}, \mathrm{F})$ Burton's, $(\mathrm{C}, \mathrm{G})$ Isle of Wight and $(\mathrm{D}, \mathrm{H})$ Gargathy Bays (listed in order of increasing areal nutrient load). Note the different scales for the water column and sediments. Error bars represent standard error for the 3 stations within each bay (except Gargathy)

March and relatively low pelagic $R$ throughout the year (Fig. 3A-D). Daily pelagic metabolism oscillated between net autotrophy and net heterotrophy in all 4 bays, though overall the water column was predominantly net autotrophic in all systems (Fig. 3A-D).

Daily sediment metabolism was more variable among the bays. In Hog Island and Burton's Bays, the sediments experienced balanced NCP most of the time, with slight oscillations from net heterotrophy in the late summer, autotrophy in the fall, heterotrophy in the spring and autotrophy in the early summer (Fig. 3E,F). Isle of Wight sediments shifted from net autotrophic to balanced over the annual cycle
(Fig. 3G), and sediment metabolism in Gargathy Bay remained net heterotrophic most of the time, with balanced metabolism in October and March (Fig. 3H). Annually, Gargathy Bay displayed the lowest rates of sediment GPP and highest rates of sediment $R$.

Combining water column and sediment metabolism into an estimate of system NEM, all 4 bays tended to be autotrophic over the sampling period (Fig. 4A-D). In Hog Island Bay, daily NEM shifted from slight heterotrophy in July and August 2007 to net autotrophy for the remainder of the study (Fig. 4A). Burton's Bay NEM followed a more seasonal pattern with net au- 


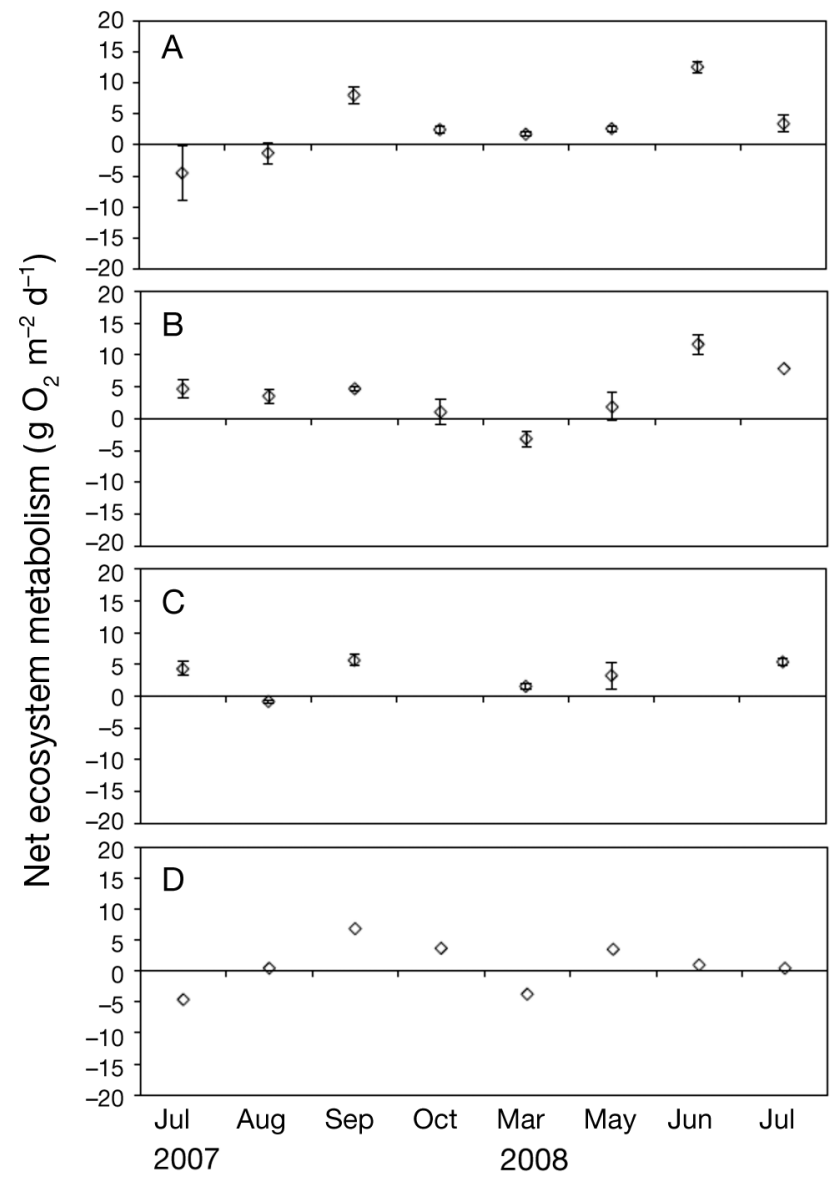

Fig. 4. Daily net ecosystem metabolism (water column + sediments) for (A) Hog Island, (B) Burton's, (C) Isle of Wight and

(D) Gargathy Bays. Error bars are as in Fig. 3

totrophy in summer and net heterotrophy in March (Fig. 4B). Isle of Wight Bay was net autotrophic over the year, except for August when it was slightly net heterotrophic (Fig. 4C). Daily NEM in Gargathy Bay was net heterotrophic or near balance in March and in the warmest months, and net autotrophic at intermediate temperatures (Fig. 4D).

Water column GPP was significantly positively correlated to water temperature and daily PAR and negatively correlated to DIN concentrations (Table 4). Water column respiration was not significantly correlated to any of the parameters tested, and only temperature was a significant driver of water column NCP. Sediment GPP was significantly negatively related to the attenuation coefficient $\left(k_{\mathrm{D}}\right)$ and sediment organic content, and positively related to DON concentrations (Table 4). Sediment respiration was negatively correlated to sediment organic content and temperature, and sediment NCP was negatively related to $k_{\mathrm{D}}$ and organic content as for sediment GPP. System NEM was positively related to water temperature and negatively related to sediment organic content (Table 4).

\section{Integrated growing season metabolism}

Daily measurements were scaled to the entire growing season (March-October) by weighting each estimate with the number of days between sampling events. Mean growing season pelagic GPP, $R$ and NCP were similar among the bays and each system experienced net autotrophy in the water column (Fig. 5A). Significant differences were limited and only detected for pelagic GPP. Integrated sediment metabolism was also similar among the bays (Fig. 5B). Isle of Wight displayed the highest rate of benthic GPP and Gargathy Bay the lowest $(p<0.001)$. Average daily benthic $R$ was not statistically different among the bays, except for Gargathy, which had the highest rate at $1.5 \mathrm{~g} \mathrm{O}_{2} \mathrm{~m}^{-2} \mathrm{~d}^{-1}(\mathrm{p}<0.001)$. Benthic NCP was significantly different among the bays $(\mathrm{p}<$ 0.001), with Isle of Wight experiencing the greatest autotrophy and Gargathy the greatest heterotrophy.

The ratio of benthic to pelagic GPP $\left(\mathrm{GPP}_{\mathrm{B}}: \mathrm{GPP}_{\mathrm{P}}\right)$ remained below 1 in all systems, indicating that water column GPP, extrapolated to a $1 \mathrm{~m}$ water column, dominated total system GPP (Fig. 5C). Isle of Wight Bay, at an intermediate areal nitrogen load, had the highest ratio, and the most nutrient-loaded system, Gargathy Bay, experienced the lowest ratio (Fig. 5C); however, no significant relationship was found with nutrient load. Isle of Wight Bay and Gargathy Bay, the 2 systems receiving the highest nutrient loads, had the highest ratio of benthic to pelagic respiration $\left(R_{\mathrm{B}: \mathrm{P}}\right)$ (Fig. $\left.5 \mathrm{D}\right)$, suggesting an increasing contribution of benthic $R$ to total system $R$ with increasing nutrient load; however, this relationship was not significant.

Integrated growing season system (water column + sediments) NEM was net autotrophic in all 4 bays (Fig. 5E,F), with a non-significant trend of increasing NEM and $P: R$ with increasing load for Hog Island, Burton's and Isle of Wight Bays, followed by significantly lower NEM and $P: R$ in Gargathy Bay at the highest load $(\mathrm{p}=0.02)$.

\section{Effect of depth on metabolic calculations}

Metabolic estimates are sensitive to water column depth. Although mean depth in these lagoons is approximately $1 \mathrm{~m}$, there has not been a rigorous hydrographic survey to better constrain mean depths. 
Table 4. Pearson correlation coefficients between metabolic and environmental parameters for the growing season (March-October). Asterisks indicate significance at the $\alpha=0.05$ level. For each parameter, the top value represents the correlation coefficient and the bottom value represents the $p$-value. The subscripts WC and SED refer to water column and sediment, respectively. CHL: chlorophyll a; DIN: dissolved inorganic nitrogen; DIP: dissolved inorganic phosphorus; DON: dissolved organic nitrogen; GPP: gross primary production; $k_{\mathrm{D} i}$ water attenuation coefficient; NCP: net community production;

NEM: net ecosystem metabolism; PAR: photosynthetically active radiation; $R$ : respiration

\begin{tabular}{|c|c|c|c|c|c|c|c|}
\hline & $\mathrm{GPP}_{\mathrm{WC}}$ & $R_{\mathrm{WC}}$ & $\mathrm{NCP}_{\mathrm{WC}}$ & $\mathrm{GPP}_{\mathrm{SED}}$ & $R_{\mathrm{SED}}$ & $\mathrm{NCP}_{\mathrm{SED}}$ & NEM \\
\hline Temperature & $\begin{array}{l}0.319^{*} \\
0.007\end{array}$ & $\begin{array}{l}0.218 \\
0.068\end{array}$ & $\begin{array}{l}0.373^{*} \\
0.001\end{array}$ & $\begin{array}{l}0.217 \\
0.07\end{array}$ & $\begin{array}{c}-0.281^{*} \\
0.017\end{array}$ & $\begin{array}{r}-0.001 \\
0.991\end{array}$ & $\begin{array}{l}0.361^{*} \\
0.002\end{array}$ \\
\hline $\mathrm{CHL}_{\mathrm{WC}}$ & $\begin{array}{l}0.217 \\
0.248\end{array}$ & $\begin{array}{l}0.03 \\
0.875\end{array}$ & $\begin{array}{l}0.189 \\
0.318\end{array}$ & $\begin{array}{c}-0.031 \\
0.87\end{array}$ & $\begin{array}{r}-0.176 \\
0.351\end{array}$ & $\begin{array}{r}-0.142 \\
0.455\end{array}$ & $\begin{array}{l}0.123 \\
0.518\end{array}$ \\
\hline $\mathrm{CHL}_{\mathrm{SED}}$ & $\begin{array}{r}-0.145 \\
0.222\end{array}$ & $\begin{array}{l}0.088 \\
0.461\end{array}$ & $\begin{array}{c}-0.054 \\
0.78\end{array}$ & $\begin{array}{l}0.338 \\
0.004\end{array}$ & $\begin{array}{c}-0.016 \\
0.89\end{array}$ & $\begin{array}{l}0.258 \\
0.028\end{array}$ & $\begin{array}{r}-0.005 \\
0.964\end{array}$ \\
\hline Daily PAR & $\begin{array}{l}0.36 \\
0.002\end{array}$ & $\begin{array}{r}-0.129 \\
0.273\end{array}$ & $\begin{array}{l}0.205 \\
0.08\end{array}$ & $\begin{array}{r}-0.093 \\
0.431\end{array}$ & $\begin{array}{c}-0.042 \\
0.72\end{array}$ & $\begin{array}{c}-0.01 \\
0.4\end{array}$ & $\begin{array}{l}0.178 \\
0.13\end{array}$ \\
\hline$k_{\mathrm{D}}$ & $\begin{array}{r}-0.078 \\
0.528\end{array}$ & $\begin{array}{l}0.038 \\
0.761\end{array}$ & $\begin{array}{r}-0.038 \\
0.758\end{array}$ & $\begin{array}{l}-0.486^{*} \\
<0.001\end{array}$ & $\begin{array}{r}-0.221 \\
0.073\end{array}$ & $\begin{array}{l}-0.557^{*} \\
<0.001\end{array}$ & $\begin{array}{r}-0.141 \\
0.257\end{array}$ \\
\hline DIN & $\begin{array}{r}-0.336 \\
0.003\end{array}$ & $\begin{array}{l}0.112 \\
0.34\end{array}$ & $\begin{array}{r}-0.196 \\
0.094\end{array}$ & $\begin{array}{r}-0.075 \\
0.523\end{array}$ & $\begin{array}{l}0.098 \\
0.408\end{array}$ & $\begin{array}{l}0 \\
0.997\end{array}$ & $\begin{array}{r}-0.19 \\
0.106\end{array}$ \\
\hline DON & $\begin{array}{l}0.229 \\
0.069\end{array}$ & $\begin{array}{r}-0.074 \\
0.559\end{array}$ & $\begin{array}{r}-0.157 \\
0.216\end{array}$ & $\begin{array}{l}0.295^{*} \\
0.018\end{array}$ & $\begin{array}{r}-0.164 \\
0.195\end{array}$ & $\begin{array}{l}0.129 \\
0.311\end{array}$ & $\begin{array}{l}0.18 \\
0.154\end{array}$ \\
\hline DIP & $\begin{array}{l}0.186 \\
0.112\end{array}$ & $\begin{array}{l}0.076 \\
0.518\end{array}$ & $\begin{array}{l}0.19 \\
0.108\end{array}$ & $\begin{array}{l}0.052 \\
0.658\end{array}$ & $\begin{array}{r}-0.108 \\
0.358\end{array}$ & $\begin{array}{r}-0.025 \\
0.831\end{array}$ & $\begin{array}{l}0.178 \\
0.13\end{array}$ \\
\hline $\begin{array}{l}\text { Sediment organic } \\
\text { content }\end{array}$ & $\begin{array}{r}-0.163 \\
0.166\end{array}$ & $\begin{array}{r}-0.077 \\
0.514\end{array}$ & $\begin{array}{r}-0.171 \\
0.144\end{array}$ & $\begin{array}{l}-0.318^{*} \\
0.006\end{array}$ & $\begin{array}{l}-0.307^{*} \\
0.008\end{array}$ & $\begin{array}{l}-0.441^{*} \\
<0.001\end{array}$ & $\begin{array}{c}-0.259^{*} \\
0.027\end{array}$ \\
\hline
\end{tabular}
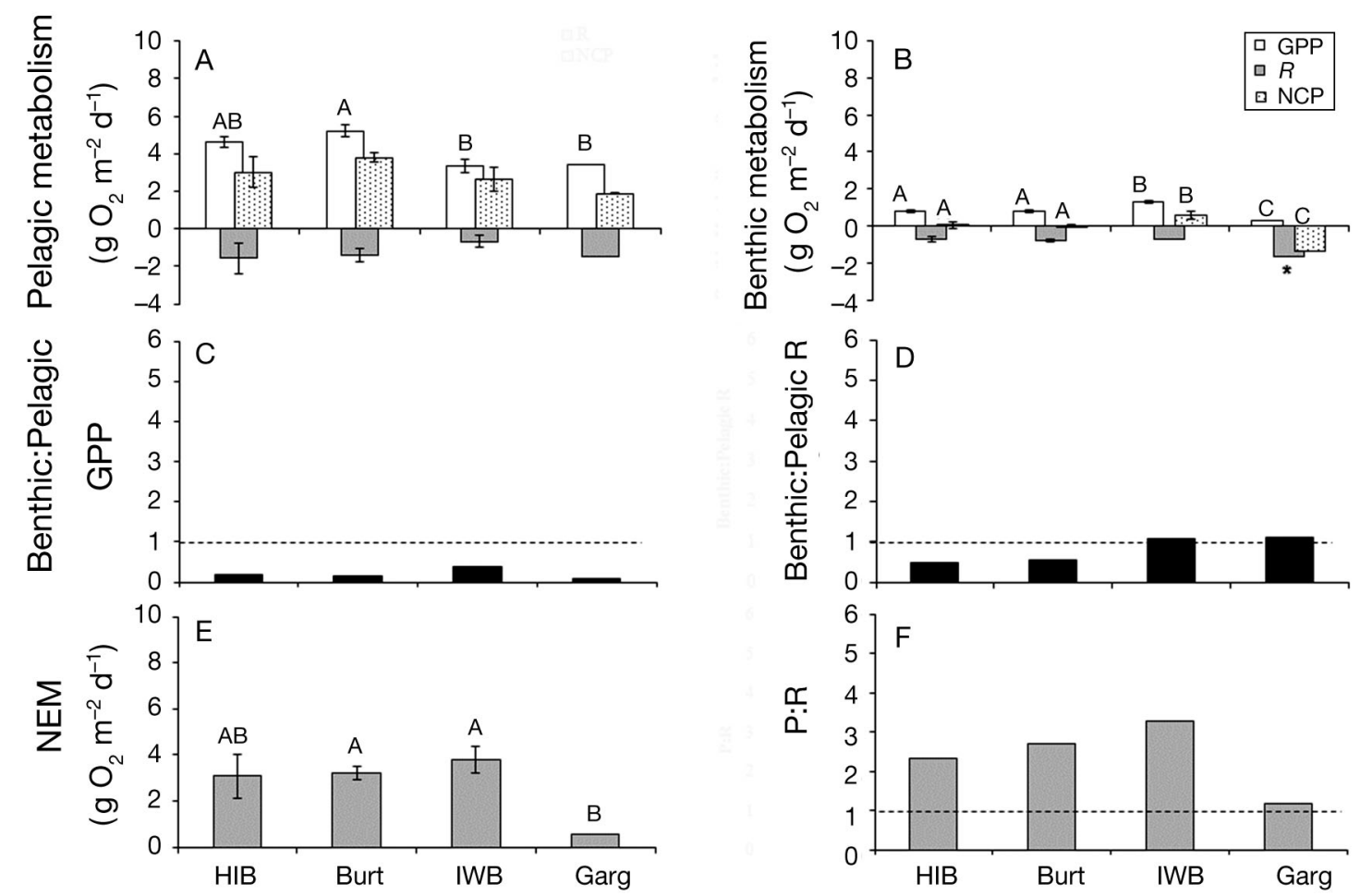

Fig. 5. Daily average gross primary production (GPP), respiration $(R)$ and net community production (NCP) for (A) the water column and (B) sediments; (C) GPP $\mathrm{GPP}_{\mathrm{P}}(\mathrm{D}) R_{\mathrm{B}}: R_{\mathrm{P}}(\mathrm{E})$ net ecosystem metabolism (NEM) and (F) production:respiration $(P: R)$ excluding macroalgae for the period between March through October for the 4 lagoons, presented along the $x$-axis in order of increasing areal nutrient load. Error bars are as in Fig. 3; statistically significant differences among lagoons ( $\alpha=0.05)$ are denoted by different letters; bays sharing a letter are not significantly different from each other 


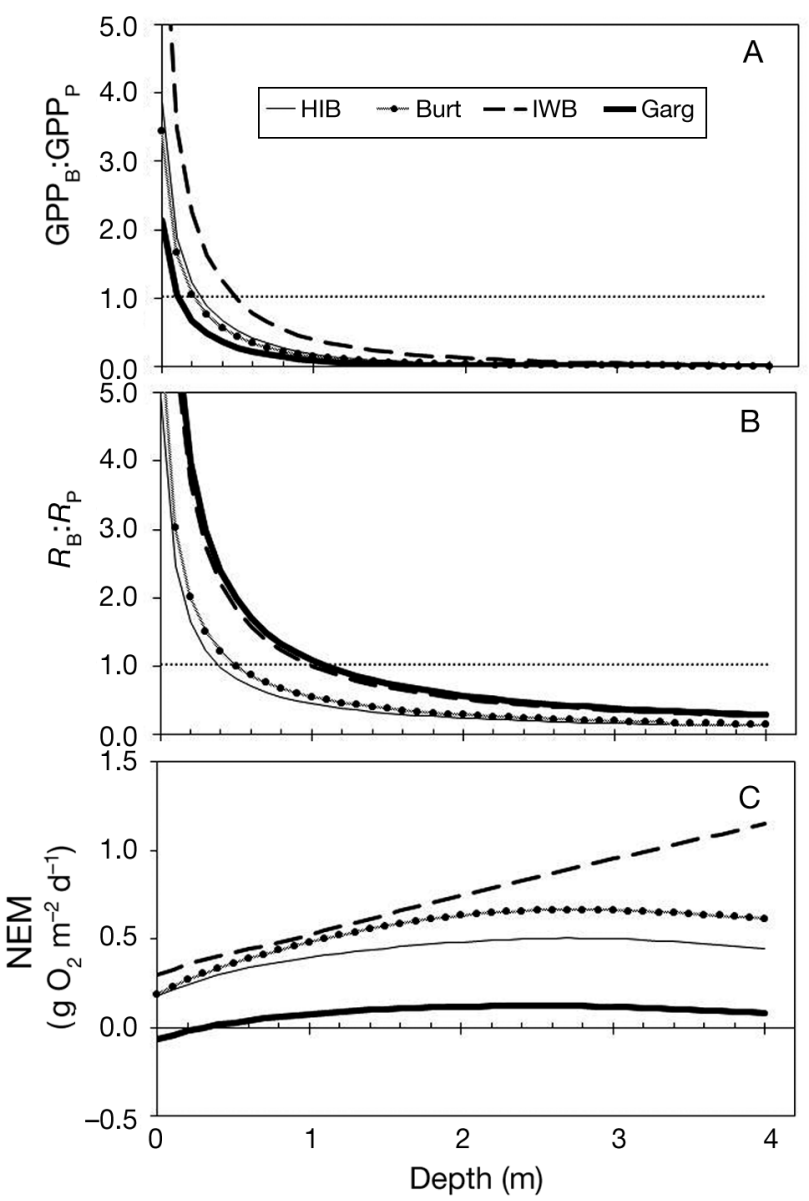

Fig. 6. Sensitivity of computed (A) benthic:pelagic gross primary production $\left(\mathrm{GPP}_{\mathrm{B}}: \mathrm{GPP}_{\mathrm{P}}\right)$, (B) benthic:pelagic respiration $\left(R_{\mathrm{B}}: R_{\mathrm{P}}\right)$ and $(\mathrm{C})$ net ecosystem metabolism (NEM) to mean lagoon depth. The dotted horizontal line in (A) and (B) represents a benthic:pelagic ratio of 1:1

Therefore, the sensitivity of $\mathrm{GPP}_{\mathrm{B}}: \mathrm{GPP}_{\mathrm{P}}, R_{\mathrm{B}: \mathrm{P}}$ and NEM to water depth (Fig. 6) was computed. Hog Island, Burton's and Gargathy Bays all shifted to pelagic dominance of GPP at depths greater than $0.2 \mathrm{~m}$, whereas pelagic GPP dominated Isle of Wight Bay at depths greater than $0.5 \mathrm{~m}$ (Fig. 6A). As mean depths in these lagoons are certainly greater than $0.5 \mathrm{~m}$, we are confident that phytoplankton productivity dominates system GPP in these lagoons. Similarly, pelagic $R$ dominated system respiration in all systems at depths greater than $1 \mathrm{~m}$ (Fig. 6B). System NEM was also sensitive to depth, with Gargathy Bay shifting from net heterotrophy to autotrophy at $0.3 \mathrm{~m}$, whereas the other lagoons remained net autotrophic with the degree of autotrophy changing with depth (Fig. 6C). Again, because mean water depths in these systems are certainly greater than $0.3 \mathrm{~m}$, we are confident in our predictions of net autotrophy across all lagoons.

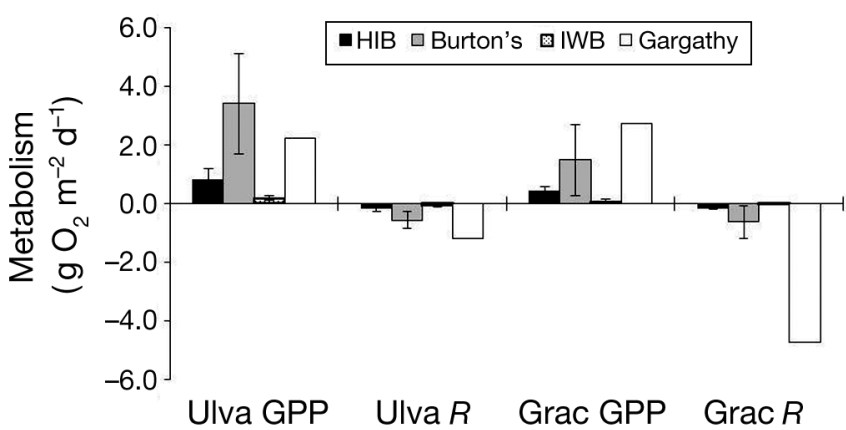

Fig. 7. Ulva and Gracilaria average daily metabolism for May through July 2008. Macroalgae gross primary production (GPP) and respiration $(R)$ account for water column attenuation, self-shading within a mixed assemblage mat and mat thickness. Error bars are as in Fig. 3

\section{Effect of macroalgae on NEM}

All macroalgal metabolic measurements were scaled to mat height and biomass for May to July, the major macroalgal growing season in these systems (Anderson et al. 2003). Average daily Ulva GPP and $R$ indicated net autotrophic Ulva mat metabolism in all 4 bays, though only slightly in Isle of Wight (Fig. 7). Gracilaria mat metabolism was net autotrophic in Isle of Wight, Hog Island and Burton's Bays, but net heterotrophic in Gargathy Bay, where the maximum rates of GPP and $R$ occurred (Fig. 7). An extensive bloom of Gracilaria occurred in Gargathy Bay during May and June, which likely caused self-shading within the mat, enhancing respiration and driving the mat net heterotrophic. Higher rates of macroalgal GPP and $R$ in Burton's and Gargathy Bays reflected the elevated macroalgal biomass observed in these systems (Table 2).

The effect of macroalgae on NEM during the active macroalgal growing season was assessed by recalculating benthic metabolism after adjusting for attenuation of light by overlying macroalgae, thus reducing microphytobenthic production, and by adding macroalgal metabolism to NEM at each site. The spatial variability of macroalgal biomass and its unknown distribution bay-wide complicated scaling macroalgal metabolism to the full system. Thus, estimates of NEM with macroalgae included do not represent integrated rates across the full lagoons, but only apply to those sites where measurements were made to provide an estimate of how macroalgae may affect the rates.

Without accounting for macroalgal shading, sediment metabolism for May to July was net autotrophic in Burton's and Isle of Wight Bays, balanced in Hog Island Bay and net heterotrophic in Gargathy Bay 


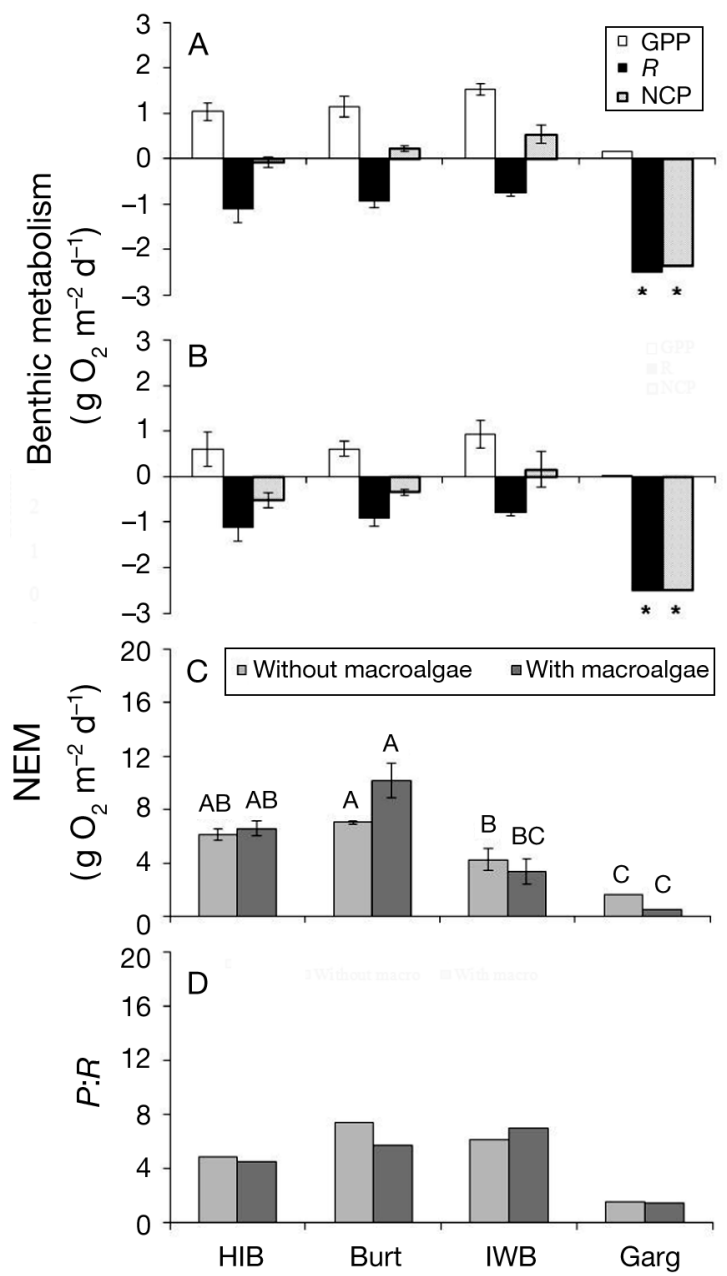

Fig. 8. Average daily benthic and system metabolism for May through July 2008 (bays are listed in order of increasing areal nutrient load). (A) Benthic metabolism without macroalgae, (B) benthic metabolism with macroalgae included, (C) net ecosystem metabolism (NEM) and (D) system production:respiration $(P: R)$. Error bars and statistical significance are as in Figs. 3 \& 5, respectively; asterisks denote statistical difference from other lagoons

(Fig. 8A). Inclusion of macroalgal shading reduced computed sediment GPP in all systems by at least $50 \%$, except in Isle of Wight Bay, and eliminated significant differences among the systems $(p=0.141$, Fig. 8B). Separate incubations of sediments collected beneath macroalgal mats in June and July displayed no significant differences in respiration relative to cores taken between mats. Thus, the low-light, organic-rich conditions that typically occur under macroalgal mats did not appear to enhance respiration of sediments covered by macroalgae, although our incubations did not reproduce potential hypoxic conditions below the mats which could reduce respiration. Macroalgal shading reduced sediment NCP in all cases, shifting Burton's Bay sediments from net

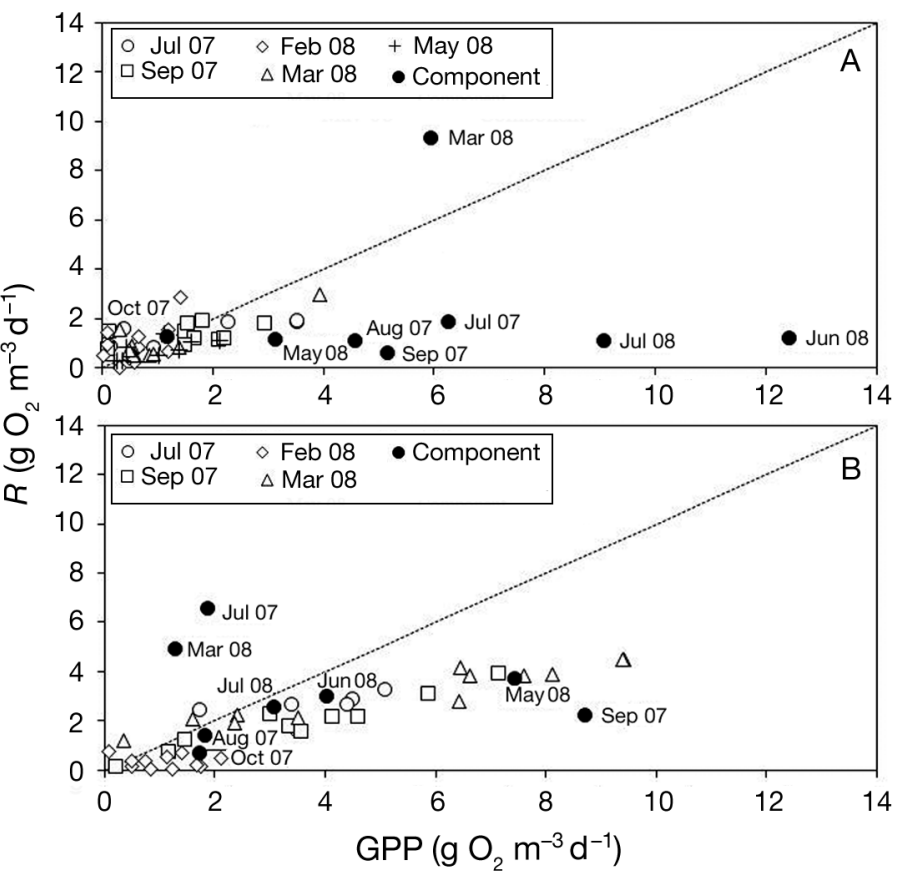

Fig. 9. Open-water metabolic measurements in (A) Burton's Bay and (B) Gargathy Bay over the annual sampling cycle. Daily net ecosystem metabolim (NEM) measured by the open-water method (open symbols) represents NEM calculated for each day of the deployment; different symbols represent different deployments. Component NEM measurements (filled circles) from the single survey each month are plotted for comparison. GPP: gross primary production; $R$ : respiration

autotrophic to net heterotrophic and Isle of Wight Bay sediments to balanced (Fig. 8B).

Adding macroalgal metabolism to total NEM at each site for May to July had varying effects on trophic status (Fig. 8C,D). In Burton's Bay, macroalgae shifted NEM towards greater autotrophy, whereas in Hog Island and Isle of Wight Bays macroalgae had virtually no effect on NEM; in Gargathy Bay, macroalgae reduced NEM to near zero. Effects of macroalgae on NEM and $P: R$ were primarily due to shading of microphytobenthic production rather than GPP and $R$ of macroalgae itself.

\section{Open-water NEM}

Open-water measurements in both Burton's and Gargathy Bays illustrated day-to-day fluctuations in rates of NEM (Fig. 9). Burton's Bay was generally in metabolic balance whereas Gargathy Bay was predominantly net autotrophic based on open-water calculations. Although measurements of NEM by the component and open-water methods were not per- 
formed concurrently, NEM measurements were made within the same month (Fig. 9). In Burton's Bay, the component method exhibited greater magnitudes of GPP and predicted more autotrophy than the open-water method (Fig. 9A). Rates from the component method in Gargathy Bay were generally similar to those from the open-water method, and both predicted a generally autotrophic lagoon (Fig. 9B).

\section{DISCUSSION}

\section{Component metabolism}

Pelagic metabolism was net autotrophic in all 4 lagoons during the growing season, which contrasted with previous studies in Hog Island Bay (McGlathery et al. 2001, Anderson et al. 2003) but was similar to other studies that report net autotrophic water columns in shallow lagoons and littoral zones of larger estuaries (Kemp et al. 1997, Smith \& Hollibaugh 1997, Smith \& Kemp 2001, Santos et al. 2004). Water temperature and daily irradiance acting to stimulate GPP appeared to drive the month-tomonth changes in rates (Table 4). Differences in pelagic metabolism in Hog Island Bay between our study and previous studies may have resulted from methodological differences, interannual variability or a long-term shift in these systems.

Resuspension of MPB in conjunction with low rates of pelagic $R$ may have contributed to the net autotrophic water columns in all lagoons. Sediment resuspension is an important physical process in these wind-driven systems (Lawson et al. 2007), and resuspended MPB has been found to contribute to water column productivity (Shaffer \& Sullivan 1988, MacIntyre \& Cullen 1995, MacIntyre et al. 1996, Lucas et al. 2001). In Burton's Bay, a significant correlation existed between benthic chlorophyll values and water column GPP ( $r=0.41, p=0.05)$, suggesting that resuspended MPB may have influenced water column processes in this system. The excretion of extracellular polymeric substances by MPB should reduce resuspension (MacIntyre et al. 1996, Lucas et al. 2001), but strong winds or tides can overcome this effect (Shaffer \& Sullivan 1988, MacIntyre et al. 1996). Without taxonomic distinction, we cannot be certain of the contribution of resuspended MPB to water column metabolism, but resuspended MPB can increase pelagic production and reduce sediment production through shading (MacIntyre et al. 1996).

Light availability (represented by the attenuation coefficient) was the primary control on sediment GPP and NCP in our shallow study lagoons (Table 4), driving 24 and $31 \%$ of the variability in these rates, respectively, a pattern also reported in other shallow systems (Stutes et al. 2006, Murrell et al. 2009). Based on measurements by the component method, pelagic metabolism dominated the NEM signal (in a $1 \mathrm{~m}$ water column). Although it has been reported that the benthos can dominate metabolism in shallow systems (Valiela et al. 1997, McGlathery et al. 2001, McGlathery et al. 2007), in the present study light availability reduced the benthic metabolic signal. In most months, areal sediment GPP at a given irradiance exceeded areal pelagic GPP at the surface, but after depth-integrating water column GPP and attenuating irradiance to the bottom, water column GPP exceeded sediment GPP. Similarly, Meyercordt \& Meyer-Reil (1999) modeled benthic metabolism in shallow coastal lagoons from PI curves and found that sites with higher light attenuation experienced reduced benthic production with increasing water column depth. Integrated metabolic values (GPP and/or $R$ ) over the depth profile in those same lagoons produced an overwhelming pelagic signal (Meyercordt et al. 1999). The dominance of pelagic metabolism in our study is likely the result of frequent wind-driven and tide-driven resuspension, which keeps turbidity high in these systems (Lawson et al. 2007).

Additional factors appeared to regulate sediment metabolism during the growing season. Significant differences in sediment metabolism existed along the TN loading gradient, with significantly higher rates in Isle of Wight Bay compared with the lagoons with lower loads, and a switch to the most heterotrophic sediments in Gargathy Bay, which had the highest load (Fig. 5B). Sediment organic content was another influential factor (Table 4), accounting for $19 \%$ of the variability in sediment NCP. Gargathy Bay had the highest sediment organic content (Table 2), which may also help explain the switch to heterotrophic sediments in this lagoon. Without quantifying the lability of the sediment organic matter, however, drawing conclusions about its role is difficult, as both quantity and quality of sediment organic content are important (Middelburg et al. 1996, Ferguson et al. 2003).

Despite finding a few significant correlations between the component rates and environmental parameters, no parameter explained the majority of the variability in the data (Table 4). It was surprising not to find more significant relationships with PAR and temperature, and not to find any relationships with chlorophyll biomass. It appears that controls on the component rates in these systems and, in turn, on 
NEM are complex and variable and thus prevent development of predictive relationships at this time.

\section{Growing season system NEM from component incubations}

The seasonality of NEM in all 4 bays (Fig. 4) agreed with previous studies in Hog Island Bay (e.g. McGlathery et al. 2001). Other studies have linked temperature and light availability to observed fluctuations in NEM (Carmouze et al. 1991, Reyes \& Merino 1991, Caffrey 2003, 2004); however, NEM was only weakly related to water temperature and PAR in our study (Table 4). Macroalgae may also have facilitated seasonal changes in NEM, as it can reduce benthic GPP through shading and influence water column metabolism by controlling the availability of nutrients (McGlathery et al. 2001, Tyler et al. 2001).

Throughout the growing season, NEM was net autotrophic in all 4 lagoons (Fig. 5). Although NEM appeared to become more autotrophic with increased nitrogen load in Hog Island, Burton's and Isle of Wight Bays (Oviatt et al. 1986, Kemp et al. 1997, Caffrey 2004), this was not a significant trend. The most nutrient-enriched system, however, did experience reduced autotrophy (Fig. 5E). Significantly reduced autotrophy in Gargathy Bay compared with the other 3 lagoons suggests the existence of a threshold for nitrogen load between 6.5 and $25 \mathrm{~g}$ $\mathrm{N} \mathrm{m} \mathrm{yr}^{-1}$ where NEM shifts towards reduced autotrophy. If nutrient load were the prime control on NEM in our study lagoons, the variation in areal nutrient loads at our sites should be adequate to detect changes in NEM, as other studies have found differences in NEM at equivalent areal nitrogen loads (Oviatt et al. 1986, D'Avanzo et al. 1996, Kemp et al. 1997, Caffrey 2003, 2004).

The ratio of inorganic nutrient to organic carbon loading (Kemp et al. 1997) may be a better predictor of NEM in coastal systems, as an increase in organic nutrient loads relative to inorganic nutrient loads tends to increase net heterotrophy (Kemp et al. 1997). Variable organic loads among the study lagoons would complicate any relationship between NEM and total nutrient loads. Total organic carbon loading has not been quantified to the systems in this study; however, Stanhope et al. (2009) found DOC and DON concentrations in base flow in the Virginia portion of the Delmarva Peninsula to be low relative to DIN and TN. Thus, the watersheds do not appear to contribute significantly to the organic load in these lagoons. A potential source of allochthonous organic loads is marsh organic carbon. However, a previous study in the fringing tidal marshes of Hog Island Bay found that these marshes were not sources of organic carbon to the lagoon (Neikirk 1996).

Internal production of dissolved organic matter (Rochelle-Newall et al. 2007, Anderson et al. 2010) could also regulate NEM in our study lagoons, as suggested by the relatively high measured DON. DON was the predominant $\mathrm{N}$ species of TDN in all 4 lagoons (Table 2), derived largely from internal recycling. In Hog Island Bay, summertime crashes of macroalgal blooms can cause a rapid increase in both dissolved organic and inorganic carbon and nitrogen (Tyler et al. 2001, 2003). Production and storage of autochthonous organic matter within the system, either from increased residence time of organic matter within a bay because of flocculation and particulate settling (Hopkinson \& Vallino 1995), or decomposition of autotrophs such as macroalgae (Viaroli \& Christian 2003), can also fuel net heterotrophy. If Gargathy Bay were experiencing high rates of internal organic loading, this could explain the high sediment organic content found in Gargathy Bay and the reduced autotrophy from respiration of this material.

\section{Effect of depth on metabolic calculations}

Estimates of NEM and the relative contribution of pelagic and sediment metabolism are highly sensitive to estimates of mean depth in shallow systems (Fig. 6). Shifts in NEM with depth demonstrate the importance of light availability to system metabolic processes (Meyercordt \& Meyer-Reil 1999, Meyercordt et al. 1999, Stutes et al. 2006, Murrell et al. 2009). In the present study, the metabolic balance of our lagoons varied with depth, sometimes switching from one state to another at depths shallower than $1 \mathrm{~m}$. Similarly, $\mathrm{GPP}_{\mathrm{B}}$ : $\mathrm{GPP}_{\mathrm{P}}$ often shifted to less than 1 at depths ranging from 0.2 to $0.8 \mathrm{~m}$ (Fig. 6A). Ratios of benthic to pelagic GPP and $R$ of less than 1 are expected with depth integration in deeper systems (Hopkinson \& Smith 2004); however, this transition occurred at a surprisingly shallow depth in our lagoons. Detailed bathymetric data for our study lagoons are not currently available; thus, mean depths of the lagoons are not well constrained. Detailed bathymetric information would enable a more accurate system-level scaling of metabolic rates. However, mean depths are certainly greater than 0.2-0.8 m, giving us confidence in our overall predictions of NEM and benthic vs. pelagic contributions. 


\section{Effect of macroalgae on NEM}

The occurrence of macroalgal blooms in the summer reduced local benthic GPP and shifted the sediments of Hog Island, Isle of Wight and Burton's Bays from balanced or slightly autotrophic to net heterotrophic (Fig. 8A,B). This shift could have resulted from reduced light availability to the sediments from macroalgal shading, thereby decreasing microphytobenthic GPP (Stutes et al. 2006), or from decomposition of macroalgae and detritus in the sediments. The significant relationships between light and sediment organic content with sediment GPP indicate that both factors might have been important in sediment metabolism (Table 3). Although no differences were detected in respiration from sediment cores taken directly under macroalgal mats, sampling might have occurred under mats that were not stationary or under which most of the labile organic matter had already been decomposed. Gargathy Bay experienced significantly greater sediment respiration in May during a Gracilaria bloom, which might have resulted from increased organic matter supply from the overlying macroalgal mat. Greater sediment respiration was also measured at the Hog Island creek sampling station in June during an extensive macroalgal bloom. Thus, greater respiration under macroalgal mats would further reduce sediment net metabolism, resulting in more heterotrophic sediments in all bays (Trimmer et al. 2000).

Macroalgal metabolism, based on the areas where biomass was sampled and growth measured, had variable effects on system NEM and $P: R$. It was anticipated that macroalgae would increase the degree of autotrophy in all lagoons given the high rates of production that must occur to produce the large mats in summer; however, this was not the case. In Gargathy Bay, the large biomass of Gracilaria was likely beginning to undergo decomposition because of self-shading within the mat, thereby shutting down algal metabolism (Brush \& Nixon 2003) and leading to heterotrophy of the mat and system (D'Avanzo \& Kremer 1994, Viaroli \& Christian 2003). The elevated water column GPP in Gargathy Bay in May could indicate a response to the release of nutrients into the water column from decomposing macroalgae (McGlathery et al. 1997, 2001).

Although extrapolations of macroalgal results are limited to a local scale, inclusion of macroalgae provides an improved estimate of whole-system NEM during the summer. Within a bay, local NEM was not significantly different. Assuming rates of local NEM hold across the bay, significant differences were found among the 4 lagoons (Fig. 8C). On a local scale, summertime system NEM peaked at a low areal nutrient load and exhibited reduced autotrophy in the 2 most nutrient-enriched systems; thus this switch to reduced autotrophy occurred at a lower nutrient load relative to the entire growing season (Fig. 5E). This was likely the result of warmer summer water temperatures stimulating greater respiration.

\section{Open-water vs. component estimates of NEM}

Although open-water and component-based estimates of NEM tended to produce similar results, the 2 methods generally predicted different magnitudes of NEM and sometimes gave opposite results (i.e. net autotrophy vs. net heterotrophy) (Fig. 9). It is not surprising that calculation of NEM using the component and open-water methods differ. In a comparison of methods, Gazeau et al. (2005) found that open-water measurements generally estimated a larger degree of heterotrophy than bottle incubations. Caffrey (2004) also found that most of the coastal systems she studied were net heterotrophic using the open-water method. In our study, the different NEM estimates calculated by the 2 methods likely resulted, in part, from differences in the hydrodynamics and physical nature of the systems, in addition to the temporal and spatial scales upon which the methods are based (Gazeau et al. 2005).

Observed differences in NEM results may also originate from assumptions inherent in both methods. The open-water method assumes that: (1) biological processes dominate over physical processes; (2) the water mass measured is homogeneous and possesses a similar metabolic history over a diel period $_{i}$ (3) metabolic rates within the system are high; and (4) air-sea exchange estimates are accurate (Kemp \& Boynton 1980, Caffrey 2003, 2004). Biases in the component method calculations result from isolating biological components from natural mixing (Kemp \& Boynton 1980), grazing and the propagation of error through calculations associated with aggregating multiple components (Smith \& Hollibaugh 1997).

Wind and tides significantly influence the physically dynamic coastal lagoons in this study. Thus, the physical nature of these systems might have violated the assumption of minimal influence of physical processes on DO levels in the system. The correction made for air-sea exchange is also subject to uncertainty. The wind data came from a 
single monitoring station inland and north of the coastal bays. It was not possible to capture the exact wind conditions at our study sites, an important factor in quantifying air-sea exchange at local scales (Kremer et al. 2003). Sensitivity analysis of the effects of wind speed on computed NEM indicated that increased or decreased wind speeds changed the magnitude of daily NEM but not the trophic status of NEM (i.e. net autotrophic or heterotrophic). The air-sea exchange correction varied between 50 and $70 \%$ of total NEM, highlighting the importance of this correction to overall NEM calculations. A single open-water monitoring station may also not accurately reflect system NEM because of spatial variability, although this represents a bigger problem in larger systems (Russell \& Montagna 2007). The location of our sondes in deeper, channel sites may also have captured more water column heterotrophy.

The extensive intertidal marshes surrounding the VA coastal bays (Table 1) could also have contributed low DO water (Neubauer \& Anderson 2003) with a high organic load (Caffrey 2004) to the lagoons. Component methods, however, should capture the respiration of organic matter exported from the marshes, as we incubated site water. In contrast, export of water with low DO concentrations because of respiration on the marsh platform may have made the open-water data indicate more respiration than was actually occurring in the lagoons. An attempt was made to correct open-water NEM for this effect using measured rates of marsh respiration (Miller et al. 2001); doing so resulted in improved correspondence in Burton's Bay but not in Gargathy Bay. These differing results using the 2 methods highlight an important area for future investigation, as many NEM studies rely on a single method (Meyercordt et al. 1999, Caffrey 2003, 2004, Santos et al. 2004, Goebel \& Kremer 2007).

\section{CONCLUSIONS}

Pelagic metabolism dominated system NEM and drove our study lagoons to net autotrophy, which departs from the conceptual model of benthic producer dominance in shallow marine ecosystems (Valiela et al. 1997, McGlathery et al. 2007). Depth and thus light availability (Meyercordt et al. 1999, Stutes et al. 2006, Murrell et al. 2009) were major factors responsible for the observed predominance of pelagic production over benthic production. Resuspended MPB might have also been a factor driving water column productivity (MacIntyre et al. 1996, Lucas et al. 2001). Macroalgae did not appear to have a significant effect on overall system NEM or $P: R$, though patchy distributions make it impossible to extrapolate these results to the system level. Some metabolic parameters demonstrated relationships with TN load; however, the patterns were not always clear or consistent. Relationships of metabolic parameters to light availability, sediment organic content, temperature and depth indicate the importance of other factors in mediating trophic response in these shallow lagoons. Differences in NEM estimates from component and open-water methods highlight the potential importance of fringing marshes and the assumptions and spatiotemporal scales associated with both methods, and underscore the need for further investigations into this discrepancy.

Acknowledgements. We thank K. J. McGlathery for her guidance regarding system and macroalgal metabolism and C. T. Friedrichs for insight into the importance of physical properties. We appreciate the field and laboratory help of B. Condon, B. Lawson, H. Wiseman, S. Fate and H. Walker. Partial support for this research was provided by the Virginia Coast Reserve Long-Term Ecological Research Program (National Science Foundation), a VIMS Eastern Shore Laboratory student research grant, and a Marlatt Foundation student research grant. This publication represents contribution number 3226 of the Virginia Institute of Marine Science, College of William and Mary.

\section{LITERATURE CITED}

Able KW (2005) A re-examination of fish estuarine dependence: evidence for connectivity between estuarine and ocean habitats. Estuar Coast Shelf Sci 64:5-17

Anderson IC, McGlathery KJ, Tyler AC (2003) Microbial mediation of 'reactive' nitrogen transformations in a temperate lagoon. Mar Ecol Prog Ser 246:73-84

Anderson IC, Stanhope JW, Hardison AK, McGlathery KJ (2010) Sources and fates of nitrogen in Virginia coastal bays. In: Kennish MJ, Pearl HW (eds) Coastal lagoons: critical habitats of environmental change. CRC Press Boca Raton, FL, p 43-72

> Beck MW, Heck KL, Able KW, Childers DL and others (2001) The identification, conservation, and management of estuarine and marine nurseries for fish and invertebrates. Bioscience 51:633-641

Beck MW, Heck KL, Able KW, Childers DL and others (2003) The role of nearshore ecosystems as fish and shellfish nurseries. Issues Ecol 11:1-12

Boesch DE (2002) Challenges and opportunities for science in reducing nutrient over-enrichment of coastal ecosystems. Estuaries 25:886-900

Borum J, Sand-Jensen K (1996) Is total primary production in shallow coastal marine waters stimulated by nitrogen loading? Oikos 76:406-410

Boynton WR, Murray L, Hagy JD, Stokes C, Kemp WM (1996) A comparative analysis of eutrophication patterns in a temperate coastal lagoon. Estuaries 19:408-412 
Bricker SB, Clement CG, Pirhalla DE, Orlando SP, Farrow DRG (1999) National estuarine eutrophication assessment: effects of nutrient enrichment in the nation's estuaries. NOAA, National Ocean Service, Special Projects Office and the National Centers for Coastal Ocean Science, Silver Spring, MD

Bricker SB, Longstaff B, Dennison W, Jones A, Boicourt K, Wicks C, Woerner J (2008) Effects of nutrient enrichment in the nation's estuaries: a decade of change. Harmful Algae 8:21-32

Brush M (2002) Development of a numerical model for shallow marine ecosystems with application to Greenwich Bay, Rhode Island. PhD dissertation, University of Rhode Island, Kingston, RI

Brush MJ, Nixon SW (2003) Biomass layering and metabolism in mats of the macroalga Ulva lactuca L. Estuaries 26:916-926

Burnham KP, Anderson DR (2002) Model selection and multimode inference: a practical information-theoretic approach, 2nd edn. Springer, New York, NY

Caffrey JM (2003) Production, respiration and net ecosystem metabolism in U.S. estuaries. Environ Monit Assess 81:207-219

Caffrey JM (2004) Factors controlling net ecosystem metabolism in U.S. estuaries. Estuaries 27:90-101

Carmouze JP, Knoppers B, Vasconcelos P (1991) Metabolism of a subtropical Brazilian lagoon. Biogeochemistry 14: $129-148$

Cloern JE (2001) Our evolving conceptual model of the coastal eutrophication problem. Mar Ecol Prog Ser 210: 223-253

> D'Avanzo C, Kremer JN (1994) Diel oxygen dynamics and anoxic events in an eutrophic estuary of Waquoit Bay, Massachusetts. Estuaries 17:131-139

> D'Avanzo C, Kremer JN, Wainright SC (1996) Ecosystem production and respiration in response to eutrophication in shallow temperate estuaries. Mar Ecol Prog Ser 141: 263-274

Duarte CM (1995) Submerged aquatic vegetation in relation to different nutrient regimes. Ophelia 41:87-112

EPA (2008) National coastal condition report III. EPA/842-R08-002. United States Environmental Protection Agency, Office of Research and Development/Office of Water. Washington, DC

Eyre BD, McKee LJ (2002) Carbon, nitrogen, and phosphorous budgets for a shallow subtropical coastal embayment (Moreton Bay, Australia). Limnol Oceanogr 47: 1043-1055

Ferguson AJP, Eyre BD, Gay JM (2003) Organic matter and benthic metabolism in euphotic sediments along shallow sub-tropical estuaries, northern New South Wales, Australia. Aquat Microb Ecol 33:137-154

Fisher TR, Gustafson AB, Sellner K, Lacouture R and others (1999) Spatial and temporal variation of resource limitation in Chesapeake Bay. Mar Biol 133:763-778

> Fisher TR, Gustafson AB, Radcliffe GM, Sundberg KL, Stevenson JC (2003) A long-term record of photosynthetically active radiation (PAR) and total solar energy at $38.6^{\circ} \mathrm{N}, 78.2^{\circ} \mathrm{W}$. Estuaries 26:1450-1460

- Gazeau F, Borges AV, Barrón C, Duarte CM and others (2005) Net ecosystem metabolism in a micro-tidal estuary (Randers Fjord, Denmark): evaluation of methods. Mar Ecol Prog Ser 301:23-41

Giordano JCP (2009) Nutrient loading and system response in the coastal lagoons of the Delmarva Peninsula. MSc thesis, College of William and Mary, Virginia Institute of Marine Science, Gloucester Point, VA

> Giordano JCP, Brush M, Anderson IC (2011) Quantifying annual nutrient loads to Virginia's coastal lagoons: sources and water quality response. Estuaries 34: 297-309

Goebel NL, Kremer JN (2007) Temporal and spatial variability of photosynthetic parameters and community respiration in Long Island Sound. Mar Ecol Prog Ser 329:23-42

> Hardison AK, Canuel EA, Anderson IC, Veuger B (2010) Fate of macroalgae in benthic systems: carbon and nitrogen cycling within the microbial community. Mar Ecol Prog Ser 414:41-55

Homer C, Huang C, Yang L, Wylie B, Coan M (2004) Development of a 2001 National Landcover Database for the United States. Photogramm Eng Remote Sensing 70: 829-840

Hopkinson CS, Smith EM (2004) Estuarine respiration: an overview of benthic, pelagic, and whole system respiration. In: Del Giorgio PA, Williams PJ le B (eds) Respiration in aquatic ecosystems. Oxford University Press, Oxford, p 122-146

> Hopkinson CS, Vallino JJ (1995) The relationships among man's activities in watersheds and estuaries: a model of runoff effects on patterns of estuarine community metabolism. Estuaries 18:598-621

> Howarth RW (2008) Coastal nitrogen pollution: a review of sources and trends globally and regionally. Harmful Algae 8:14-20

Howarth RW, Marino R (2006) Nitrogen as the limiting nutrient for eutrophication in coastal marine systems: evolving views over three decades. Limnol Oceanogr 51: 364-376

Jassby AD, Platt T (1976) Mathematical formulation of the relationship between photosynthesis and light for phytoplankton. Limnol Oceanogr 21:540-547

- Kemp WM, Boynton WR (1980) Influence of biological and physical processes on dissolved oxygen dynamics in an estuarine system: implications for measurement of community metabolism. Estuar Coast Mar Sci 11:407-431

Kemp WM, Smith EM, Marvin-DiPasquale M, Boynton WR (1997) Organic carbon balance and net ecosystem metabolism in Chesapeake Bay. Mar Ecol Prog Ser 150: 229-248

Knepel K, Bogren K (2001) Determination of orthophosphate by flow injection analysis. QuikChem Method 21-11501-1-H. Lachat Instruments, Milwaukee, WI

> Kremer JN, Reischauer A, D'Avanzo C (2003) Estuary-specific variation in the air-water gas exchange coefficient of oxygen. Estuaries 26:829-836

Lawson SE, Wiberg PL, McGlathery KJ, Fugate DC (2007) Wind-driven sediment suspension a shallow coastal lagoon. Estuar Coasts 30:102-112

Liao N (2001) Determination of ammonia in brackish or seawater by flow injection analysis. QuikChem Method 21107-06-1-B. Lachat Instruments, Milwaukee, WI

Lorenzen C (1967) Determination of chlorophyll and phaeopigments: spectrophotometric equations. Limnol Oceanogr 12:343-346

Lucas CH, Banham C, Holligan PM (2001) Benthic-pelagic exchange of microalgae at a tidal flat. 2. Taxonomic analysis. Mar Ecol Prog Ser 212:39-52

> MacIntyre HL, Cullen JJ (1995) Fine-scale vertical resolution of chlorophyll and photosynthetic parameters in shallow-water benthos. Mar Ecol Prog Ser 122:227-237 
MacIntyre HL, Geider RJ, Miller DC (1996) Microphytobenthos: The ecological role of the 'secret garden' of unvegetated, shallow-water marine habitats. I. Distribution, abundance, and primary production. Estuaries 19: 186-201

Marino R, Howarth RW (1993) Atmospheric oxygen exchange in the Hudson River: dome measurements and comparison with other natural waters. Estuaries 16: 433-445

> McGlathery KJ, Krause-Jensen D, Rysgaard S, Christensen PB (1997) Patterns of ammonium uptake within dense mats of the filamentous Chaetomorpha linum. Aquat Bot 59:99-115

> McGlathery KJ, Anderson IC, Tyler AC (2001) Magnitude and variability of benthic and pelagic metabolism in a temperate coastal lagoon. Mar Ecol Prog Ser 216:1-15

McGlathery KJ, Sundback K, Anderson IC (2007) Eutrophication in shallow coastal bays and lagoons: the role of plants in the coastal filter. Mar Ecol Prog Ser 348:1-18

> Meyercordt J, Meyer-Reil LA (1999) Primary production of benthic microalgae in two shallow coastal lagoons of different trophic status in the southern Baltic Sea. Mar Ecol Prog Ser 178:179-191

Meyercordt J, Gerbersdorf S, Meyer-Reil LA (1999) Significance of pelagic and benthic primary production in two shallow coastal lagoons of different degrees of eutrophication in the southern Baltic Sea. Aquat Microb Ecol 20: 273-284

Middelburg JJ, Klaver G, Nieuwenhuize J, Wielemaker A, de Haas W, Vlug T, van der Nat JFWA (1996) Organic matter mineralization in intertidal sediments along an estuarine gradient. Mar Ecol Prog Ser 132:157-168

Miller WD, Neubauer SC, Anderson IC (2001) Effects of sea level induced disturbances on high salt marsh metabolism. Estuaries 24(3):357-367

> Murrell MC, Campbell JG, Hagy JD, Caffrey JM (2009) Effects of irradiance on benthic and water column processes in a Gulf of Mexico estuary: Pensacola Bay, Florida, USA. Estuar Coast Shelf Sci 81:501-512

Neikirk BB (1996) Exchanges of dissolved inorganic nitrogen and dissolved organic carbon between salt marsh sediments and overlying tidal water. MSc thesis, College of William and Mary, Virginia Institute of Marine Science, Gloucester Point, VA

> Neubauer SC, Anderson IC (2003) Transport of dissolved inorganic carbon from a tidal freshwater marsh to the York River Estuary. Limnol Oceanogr 48:299-307

Nixon SW (1995) Coastal marine eutrophication: a definition, social causes, and future concerns. Ophelia 41: 199-219

- Nixon S, Buckley B, Granger S, Bintz J (2001) Response of very shallow marine ecosystems to nutrient enrichment. Hum Ecol Risk Assess 7:1457-1481

Odum HT, Hoskins CM (1958) Comparative studies of the metabolism of marine waters. Publ Inst Mar Sci Texas 5: $16-46$

> Oviatt CA, Rudnick DT, Keller AA, Sampou PA, Almquist GT (1986) A comparison of system $\left(\mathrm{O}_{2}\right.$ and $\left.\mathrm{CO}_{2}\right)$ and C14 measurements of metabolism in estuarine mesocosms. Mar Ecol Prog Ser 28:57-67

> Peckol P, Rivers JS (1996) Contribution by macroalgal mats to primary production of a shallow embayment under high and low nitrogen loading rates. Estuar Coast Shelf Sci 43:311-325

> Pemberton M, Anderson GL, Barker JH (1996) Characteri- zation of microvascular vasoconstriction following ischemia/reperfusion in skeletal muscle using videomicroscopy. Microsurgery 17:9-16

Pinckney J, Zingmark RG (1993) Biomass and production of benthic microalgal communities in estuarine habitats. Estuaries 16:887-897

Quinn GP, Keough MJ (2002) Experimental design and data analysis for biologists. Cambridge University Press, Cambridge

Reyes E, Merino M (1991) Diel dissolved oxygen dynamics and eutrophication in a shallow, well-mixed tropical lagoon (Cancun, Mexico). Estuaries 14:372-381

> Rochelle-Newall EJ, Winter C, Barron C, Borges AV and others (2007) Artificial neural network analysis of factors controlling ecosystem metabolism in coastal systems. Ecol Appl 17:S185-S196

Russell MJ, Montagna PA (2007) Spatial and temporal variability and drivers of net ecosystem metabolism in Western Gulf of Mexico estuaries. Estuar Coasts 30:137-153

Santos R, Silva J, Alexandre A, Nuvarro N, Barron C, Duarte CM (2004) Ecosystem metabolism and carbon fluxes of a tidally-dominated coastal lagoon. Estuaries 27:977-985

Shaffer GP, Sullivan MJ (1988) Water column productivity attributable to displaced benthic diatoms in well-mixed shallow estuaries. J Phycol 24:132-140

Shoaf WT, Lium BW (1976) Improved extraction of chlorophyll a and b from algae using dimethyl sulfoxide. Limnol Oceanogr 21:926-928

Smith P, Bogren K (2001) Determination of nitrate and/or nitrite in brackish or seawater by flow injection analysis colorimetry. QuikChem Method 31-107-04-1-E. Lachat Instruments, Milwaukee, WI

Smith SV, Hollibaugh JT (1997) Annual cycle and interannual variability of ecosystem metabolism in a temperate climate embayment. Ecol Monogr 67:509-533

Smith EM, Kemp WM (2001) Size structure and the production/respiration balance in a coastal plankton community. Limnol Oceanogr 46:473-485

Stanhope JW, Anderson IC, Reay WG (2009) Base flow nutrient discharges from lower Delmarva Peninsula watersheds of Virginia, USA. J Environ Qual 38: 2070-2083

> Stutes AL, Cebrian J, Corcoran AA (2006) Effects of nutrient enrichment and shading on sediment primary production and metabolism in eutrophic estuaries. Mar Ecol Prog Ser 312:29-43

> Tobias CR, Cieri M, Peterson BJ, Deegan LA, Vallino J, Hughes J (2003) Processing watershed-derived nitrogen in a well-flushed New England Estuary. Limnol Oceanogr 48:1766-1778

Trimmer M, Nedwell DB, Sivyer DB, Malcolm SJ (2000) Seasonal organic mineralisation and denitrification in intertidal sediments and their relationship to the abundance of Enteromorpha sp. and Ulva sp. Mar Ecol Prog Ser 203: $67-80$

> Tyler AC, McGlathery KJ, Anderson IC (2001) Macroalgae mediation of dissolved organic nitrogen fluxes in a temperate coastal lagoon. Estuar Coast Shelf Sci 53:155-168

Tyler AC, McGlathery KJ, Anderson IC (2003) Benthic algae control sediment: water column fluxes of organic and inorganic nitrogen compounds in a temperate lagoon. Limnol Oceanogr 48:2125-2137

Valiela I, Foreman K, LaMontagne M, Hersh D and others (1992) Couplings of watersheds and coastal waters: sources and consequences of nutrient enrichment in 
Waquoit Bay, Massachusetts. Estuaries 15:443-457

> Valiela I, McClelland J, Hauxwell J, Behr PJ, Hersh D, Foreman K (1997) Macroalgal blooms in shallow estuaries: controls and ecophysiological and ecosystem consequences. Limnol Oceanogr 42:1105-1118

Editorial responsibility: Matthias Seaman, Oldendorf/Luhe, Germany
Viaroli P, Christian RR (2003) Description of trophic status, hyperautotrophy and dystrophy of a coastal lagoon through a potential oxygen production and consumption index - TOSI: Trophic Oxygen Status Index. Ecol Indic $3: 237-250$

Submitted: July 24, 2010; Accepted: March 12, 2012

Proofs received from author(s): June 23, 2012 